\title{
Corruption and Anticorruption in the Czech Republic
}

\author{
By: Lubomír Lizal and Evžen Kočenda
}

Working Paper Number 345

October 2000 


\title{
Corruption and Anticorruption in the Czech Republic
}

\author{
Lubomír Lízal and Evžen Kočenda \\ CERGE-EI, Prague, Czech Republic \\ W. Davidson Institute, University of Michigan Business School, USA \\ CEPR, London
}

\begin{abstract}
:
It is widely acknowledged that corruption has negative impact on economy and society. Transition process in the Central and Eastern Europe (CEE) uncovered dormant possibilities for corruption that consequently required appropriate steps to be taken against. We attempted to document the state of corruption in the Czech Republic and the measures introduced to fight it. We covered sectors of society and economy according to their importance in the prevention of a corruption and a consequential hazard to the society. We also described the governmental concept of anti-corruption measures and outlined achievements and failures of such a program. The overall impression favors persistent presence of corruption within the society and economy in the Czech Republic. The state of corruption in the country, measured by the Corruption Perception Index, presents a serious problem since the index does not improve as transition process advances. Numerous comparative studies, however, suggest that corruption is more prominent feature in a number of other transition countries. We believe that the institutional framework to prevent and fight corruption appears to be improving.
\end{abstract}

Keywords: corruption, institutions, transition, hidden economy, administration

JEL Classification: H50, I20, K42, O17, P27, Z13

An earlier draft of the paper served as a background study on corruption and anticorruption issues in the Czech Republic for ,Anticorruption in Transition: A Contribution to the Policy Debate", published by the World Bank, Washington, DC, 2000, ISBN 0-8213-4802-7. The authors acknowledge support of the World Bank and the William Davidson Institute at the University of Michigan Business School. 


\section{Non-technical Summary}

The corruption in the transition countries has become more severe problem as these countries increase their openness and involvement in the international communities and organizations. With a dramatic change in the Czech political regime in 1989, the whole process of social and economic transformation initiated changes in the environment of corruption. In this article we attempted to document the state of corruption in the Czech Republic and the measures introduced to fight it. To understand the evolution of corruption under new conditions of transition process we had to tackle historical roots and origins of corruption.

In addition to the classical division on high-level corruption that involves elected and senior public officials and on low-level corruption that involves mid and low level bureaucrats we cover sectors of society and economy according to their importance in the prevention of a corruption and a consequential hazard to the society. Based on such comparison over different categories where bribery may occur the following hierarchical division of corruption occurrence is formed:

1. Police, State Prosecution, Judicatory and Court Systems including Parliament and Government,

2. Tax and Fiscal Authorities, Licensing Laws and Procedures, Public Tenders, Monopoly Regulation, and State, Local and Municipal Administrations,

3. Education, Health Care, and Social Care,

4. Private Businesses and Citizens.

Each category listed above is discussed in detail with its linkages to other categories. The licensing in addition to economic sectors with natural monopoly elements also covers bank and finance licensing. The monopolies are also dealt with in a special section. Unlike in western economies, a special attention is paid to the area of state social assistance. For example, the health system is designed in such a way that the patient is not able to recognize whether the service is adequate or too expensive or redundant, or to discover that the provider has charged the insurance company for non-performed services or non-supplied drugs.

Among the two basic methods, how to measure the corruption we prefer the one that is based on opinion pools, surveys, and case studies. These measures are less precise, however they more realistically reflect the situation in the country and/or particular sector compared to those based on documented cases and hard numbers since these are not able to measure the latent 
corruption. It means, that in the highly corrupted environment, where any true and independent investigation is impossible, such measure can give an extremely low level of corruption. The state of corruption in the country, measured by the Corruption Perception Index, presents a serious problem since the index does not improve as transition process advances. For example, according to the CPI the corruption environment in both Czech and Slovak Republics is slowly gaining strength. Current forms of corruption have the same origin in the Czech and Slovak Republics due to the common experience in the former Czechoslovakia. This measure has long lasting negative trend in both countries.

We also described the governmental concept of anti-corruption measures and outlined achievements and failures of such a program. It is understood that the concept of anti-corruption measures must be systematically linked with steps that deal with other social problems. Thus the goal of the Program of Combating Corruption is to describe the nature and objectives of combating corruption, define its principal methods and means, propose specific measures to be taken in respective areas, define responsibilities and a time schedule, and indicate the method of monitoring. We look at such program in line with its three major components. First, there is Educational Program to increase awareness about corruption and ability of civil servants to fight it. Second, there was launched so-called governmental campaign "Clean Hands" and finally we look at the improvements and disimprovements of legal system and evaluate the proposed changes.

The overall impression favors persistent presence of corruption within the society and economy in the Czech Republic. Numerous comparative studies, however, suggest that corruption is more prominent feature in other transition countries with economies of the former Soviet Union leading the pack. Nevertheless, the state of corruption in the country, measured by the CPI, presents a serious problem since the index does not improve as transition process advances. We believe that the institutional framework to prevent and fight corruption is improving, though. 


\section{Introduction}

It is widely acknowledged and supported by numerous studies that corruption has negative impact on economy and society. The economic and social transformation in the Central and Eastern European (CEE) countries inevitably created and enhanced opportunities where corruption could easily flourish. The corruption in the transition countries has become more severe problem as these countries increase their openness and involvement in the international communities and organizations. This analysis aims to document the state of corruption in the Czech republic and the measures introduced to fight it.

With a dramatic change in the Czech political regime in 1989, the whole process of social and economic transformation initiated changes in the environment of corruption. There exist particular shifts in corruption from one area to another that occurred along with economic and legal transformation, and sometimes led to a growth in large-scale corruption. Corruption shifted primarily from the region of general services and sales to the region of state clerical/ administrative services.

In order to understand the evolution of corruption under new conditions of transition process we have to tackle, at least briefly, historical roots and origins of corruption. Comparison with corruption scheme common under the communist regime, which was based mainly on the mutual friendly services, and time dependent evolution of corruption shows, that the legislation was quite appropriate to punish the classical bribery corruption of state officials. It was, however, completely inappropriate to prevent the newly emerged forms of corruption associated with rent seeking.

Moreover, the old common approach based on the services, small gifts, and small bribes has sustained even up to date since it evolved during the communist past to be a norm of behavior and negotiation with the state administration. In the past, the general public perceived as a repressive body any part of the state administration. Since the state was an "enemy," smallscale misuse and theft of the public goods and sources became a part of the passive opposition against the communist regime. Of course, after forty years such behavior had to become not only a socially acceptable norm and sometimes even a norm of proper morale not only on the citizens' level but also on the administrative level.

General public does not perceive the state administration at any level as a socially prestigious and valuable occupation. The income of the administration is relatively low and almost no income differentiation exists. Consequently, the state administration is not a competitive job opportunity on the labor market, and does not attract the skilled people. As the result the system as a whole is extremely bureaucratic. These symptoms cause that administrative officials almost at any level do not belong to the middle-class. Therefore the low-level administrative staff is often unqualified and unable to make any independent decision and to take personal responsibility for such decisions. Thus, the prevailing tendency is to delegate responsibility to resolve pertinent matter on higher level within the administration structure. In 
addition, the front-desk clerks often compensate their feeling-of-non-importance by unfriendly approach and bureaucratic rigidity toward general public. The general practice of all state administration requires the citizens to use specific part of administration according their socalled permanent residency. This means that not only the procedure depends on the interpretation of rules by the regional (local) office but also the citizen cannot use administration in another region. Semi-private institutions, like a major health insurance company, are mimicking the state administration behavior.

These roots might be the main reason why the recent changes, which are presented to the public as a harmonization with the EU norms, represent a yisible increase in the power of state administration in its discretionary decisions as a by-product.

With the previous account in mind we can divide corruption, albeit somehow artificially, into two dominant forms:

\section{High-level corruption involves elected and senior public officials.}

Such a category covers, in particular, financing of political parties and their election campaigns, inadequate parliamentary lobbying activities, and public tenders at any level of state administration. Lobbying at high-level administration does not mostly contain features of transparent process known in Western democracies. Instead, it resembles rent seeking activities of political and business influential groups. Rose-Ackerman (1999) provides a comprehensive analysis of relationship of corruption and government, specifically in cases of corruption that occurs at the highest levels of government and involves major government projects and programs. The economic impact of corruption is examined extensively.

\section{Low-level corruption involves mid and low level bureaucrats.}

In this respect, the classification refers to municipalities, all forms of public services provided by the state through regional and local agencies, as well as state guaranteed health care. Such level also entails informal links among private companies themselves and low-level state bureaucracy. According the recent EBRD survey (EBRD, 1999), the main obstacles to the growth of small and medium enterprises (SME) are anti-competitive practices and corruption, followed by taxes and business regulations. A priority for the next decade of transition is to embrace competition policy that focuses on reducing barriers to business start-ups, introducing measures to combat corruption and crime and hardening the budget constraints on declining industrial enterprises. Lizal and Svejnar (2000) show that problems with soft-budget constraint persist in the Czech economy, mainly via banking sector. Thus, credit related corruption possibilities are well warranted to be studied.

Further spread of corruption embraces direct economic activities as well as less direct ways through administrative processes. On aggregate or macroeconomic level the costs of

\footnotetext{
${ }^{1}$ For example, there are proposed changes in the hunting law to prevent poaching. The new law would put the status of hunters on the same level as that of policemen, however, without the qualification requirements the police should meet.
} 
corruption should be emphasized in terms of economic growth. During transition process the fight against corruption is surely not cheap and cannot be independent from the reform of the state. If certain reforms are not made, corruption is likely to continue to be a problem regardless of actions directly aimed at curtailing it.

\section{Sector Comparison of Dominant Forms of Corruption}

We now proceed with a classification and description of dominant forms of corruption according to different sectors of society where corruption appears.

Although all forms of corruption are socially and economically dangerous, we can divide the sectors into four groups according their importance in the prevention of a corruption and a consequential hazard to the society. The first group consists of sectors, which were also designed to fight with the corruption and to guarantee legal status. The second group consists of various ways of the state administrations. The third area consists of services provided by the state and society to the general public and citizens and the last one involves a private sector and citizens themselves.

Despite the fact that we provide possible means of corruption, there is little evidence in the criminal prosecution of all these forms. Therefore, we include major known cases as illustrative examples whenever possible. Our division is made in such a way that the members of the subsequent category have more incentive to corrupt the members of the preceding one than to be corrupted from this one. Therefore, the hierarchy we use describes mainly the ways of receiving bribes. However, one should keep on mind that corruption is not a strictly one-way process.

The Table 1 illustrates how the perception of corruption by ordinary citizens has changed over the first decade of transition process. The numbers in a table also implicitly show in which sector the resources are scarcer and their rationing does not function properly. Two major changes are immediately visible. Services and sales in general, e.g. all categories that were already almost completely privatized, show a dramatic decline in perceived corruption. State administration, on other hand, records an almost tenfold increase in corruption perceived by citizens. 
Table 1

Question: In Which Area Is the Bribery Most Prevalent? (in \%)

\begin{tabular}{|l|c|l|c|}
\hline \multicolumn{1}{|c|}{ Sector } & 1989 & \multicolumn{1}{c|}{ Sector } & 1998 \\
\hline State Administration & 3 & State Administration & 31 \\
Sales and Repair & 11 & Judicatory System & 15 \\
Health Services & 21 & Health Services & 15 \\
Transport, Construction Materials & 5 & Police & 9 \\
Services & 31 & Services & 9 \\
Education & 1 & Education & 2 \\
Restaurants & 3 & Restaurants & 2 \\
Retail Sales & 26 & Army & 0 \\
\hline
\end{tabular}

*Source: Výzkumný ústav obchodu, 1989, N=1643, data for Czechoslovakia.

**Source: GfK - Praha, April 1998, N=967, data for Czech Republic.

Based on the above intertemporal comparison over different categories where bribery may occur the following hierarchical division of corruption occurrence is formed:

1. Police, State Prosecution, Judicatory and Court Systems including Parliament and Government,

2. Tax and Fiscal Authorities, Licensing Laws and Procedures, Public Tenders, Monopoly Regulation, and State, Local and Municipal Administrations,

3. Education, Health Care, and Social Care,

4. Private Businesses and Citizens.

In addition, all the institutions, with the exception of the private firms in the last category, are fully or partly financed through public finance budgets. Hence, there is always a possibility for the representative of this group to try to corrupt any member(s) of the previous (upper) category to increase either financial means allocated or competence on usage of the allocated funds. One of the main reasons for presence of corruption in private businesses is caused by persistent presence of soft-budget constraints.

In the subsequent subsections we list possible ways of corruption for each part of the state administration separately. The system of police work, prosecution and court system is a quite complex one to be described in detail and beyond the scope of this paper. Therefore we do not describe this part of the system and we focus directly on the possible methods of corruption only.

\subsection{Police and Investigation}

A major sustaining conceptual problem prevails from the communist past, and is common both to the general public and state administration. The police are still viewed as a repressive part of the state administration and not as a major contribution to a crime prevention 
and their natural authority and public appearance are perceived as a simplest way to keep the public order.

In particular, the most susceptible to the low-level corruption are those parts of police that are in the direct contact with general public. The main reasons for corruption include inadequate incentive schemes, inadequate technical equipment of the police, at certain cases undefined legal status of policeman, poor management and controlling, and management of human resources and qualification of the newly accepted staff. Currently, the lack of qualified labor is suggested to be solved by reducing the required educational standards.

Each corruption in the police involves the misuse of power while not each misuse of the power involves the corruption. The exact forms of corruption depend on the specific situations and also vary with the specific departments (criminal, traffic, foreign and border service, and alike). The most visible part involves the traffic police since the traffic fines (especially those for speeding or driving after drinking any alcoholic beverage or intoxicated) are more or less arbitrary and certain fines could be paid on the spot.

We can identify two basic types of police power misuse related to corruption. The first one involves the expected various forms of crime cover-ups. The second one is just the opposite: to find and discover even nonexistent criminal acts in the anticipation of possible promotion and pay rise. The aforementioned forms of corruption starts from receiving free services, over slow acting or inaction during investigation, to racketeering, providing coverage for criminal acts, hiding the evidences, protectionism, providing information on the status of criminal investigation and the undergoing intelligence actions to the criminals. In 1999, 345 policemen were investigated for more than 500 criminal delinquencies. The highest proportion of police delinquencies was found among officials under the age of 29, and service shorter than 5 years (report of the Police for 1999).

\subsection{State Prosecution (State Attorney Offices)}

The prosecution is designed to monitor the investigation, to decide whether the investigation is in the stage when the indictment should be filed in or whether to drop the case. The prosecutor at higher level can always override the decision of a lover-level prosecutor. Such controlling mechanisms make the possibility to corrupt the (state) prosecutor more complex than to corrupt the police and hence the corruption is less likely. On the other hand, the prosecutors' decisions can waste the police investigation and a corrupted high-level prosecutor can almost paralyze the system. Finally, the methods of corruption would be quite similar to those used to corrupt the police.

A specific feature is that the prosecutors can decide independently on each other. This causes situations where in limiting cases prosecution at a certain district considers one specific behavior as a criminal one while prosecution located in other district considers similar cases as non-illegal ones and stops the investigation. This, of course, opens a space for corruption, 
especially in these limiting cases where the interpretation of the law is not straightforward.

\subsection{Judicatory and Court Systems including Parliament and Government}

The judges are independent on the state in the Czech Republic and only the law limits them. Such a feature makes their decision making really independent on the interests of any group. On the other hand, the tradition in the decisions is to focus more on the formal aspects of the case than to interpret the law (extensive interpretation).

This is driven not only by the nature of the Continental law but also by the historical tradition. The decision making in transition periods when the laws are not adequate to the rapidly changing environment has severe limitations compared to the case-law approach, or at least, more extensive approach in the case judgement.

Looking at the recent past, vast amount of legal economic cases would be considered illegal in the West (for example, so-called Ponti's scheme and similar ones) while the Czech legislation was not explicitly mentioning these types of behavior as illegal. Therefore, the whole Czech stock market became almost worldwide infamous because of its lack of transparency, price manipulation and abuse of power by shareholders with majority stakes. Although the situation started to improve during the last years when the Exchange and Securities Commission was established and new laws were approved by Parliament. ${ }^{2}$

The current government declared its interest to fight corruption and its program "Clean Hands" was a major election topic. ${ }^{3}$ On the other hand its effort can not be seen as fully credible. Both major parties in the Czech Republic, social democrats and civic democrats, are suspected and investigated, or their members are ynder investigation, for use of illegal funds, misuse of economic information, and tax evasions.

As a final note, unfortunately there is quite a lot of lobbying in the Lower House of Parliament involved. We can judge this on the basis of the amendments and modifications suggested (and approved) during the final (third) reading. These modifications of newly accepted laws become a part of the law (if accepted) even if they were not aforementioned during the previous readings. A perfect illustration is the Property Execution Act. The intention of the law was to allow better debt repayment in cases of default and indirectly to speed up the bankruptcy

\footnotetext{
${ }^{2}$ The initial attitude towards the privatization process and the regulation of the stock exchange can be illustrated by a controversial statement made by former Minister of Finance, Mr. Klaus: "I do not know a method to distinguish dirty and clean money in practice; to do so would mean to cast doubts about the process of small privatization, I think it would not be a good decision", in an interview for the Czech Press Agency (CTK), September 27, 1999.

${ }^{3}$ More on this can be found in other section.

${ }^{4}$ Former Minister of Finance in the current social democrats' government is investigated for asset stripping. A former minister responsible for EU coordination was found to have illegal deposits abroad and is suspected of receiving provisions and tax evasion. Moreover, one of the Prime Minister's advisors was publicly accused of blackmailing and the case is under investigation. Civic democrats are suspected of illegal financing, Swiss police confirmed this suspicion in part by acknowledging the existence of a suspicious account in one Swiss bank, investigation is still under process.
} 
procedures. However, in the third round all firms were excluded so only citizens' properties could be execution levied on.

\subsection{Tax and Fiscal Area}

The Czech laws are quite strict in the collection of income taxes and there are only few ways of possible leakage. However, there exist groups of approximately five officials at the Ministry of Labor and Social Affairs and at the Ministry of Finance who can forgive fines for late payment of taxes and social security payments. The decisions are in reality made ad hoc; the procedure has even no rules that would describe the process and therefore justify the exceptions granted. Moreover, existence of such groups is not known to general public, hence, the citizens (and small ordinary taxpayers) even do not know that they can apply for the pardon.

Although the tax law is quite transparent, the associated laws on health insurance and social security are more complex and less transparent. The employees even do not see on their paychecks that two thirds of the social and health payment is constructed as a payroll tax and directly paid by the employer. An implicit illustration of ignorance as for the level of such contributions was an opinion pool held on this topic by the STEM agency in 1998. The respondents indicated that the rich should pay higher taxes, about $25 \%$ of the net income. Such a perception is in sharp contradiction with reality since at that time the high-income brackets defined tax payments as $39 \%$ of the net income - after payment of almost $40 \%$ of health and social insurance. The illustrative example of average shares of income tax, various taxes like payroll and a net income can be found in Turnovec (1999).

The remaining segments of the fiscal system and administration are more problematic. There are quite common frauds in the value-added tax (VAT) collection and collection of consumption (excise) taxes and custom duties. These frauds are estimated in billions of Czech crowns $(\mathrm{CZK})$ and there are links with international crime. Similar cases are reported to occur in Poland and Hungary. In this area we face not only corruption but also highly organized international criminal activities. Quite a popular scheme in the middle of the 1990's can serve as an example to refer to. The imported oil (petroleum) products were declared to be for heating purposes but in reality it was a truck fuel. After the custom clearance the declared heating oil was sold as a truck fuel. The unpaid consumption tax comprises more than one half of the final sale price. The total state revenue from truck fuel consumption tax was 17.5 billion CZK in 1996 and the loss in tax revenues was estimated at 2.5 billion CZK. Of course, such activity required at least passive attitude of the state administration.

During the first half of 1990's the evasion from payment of consumption tax on alcoholic beverages and cigarettes was alarming. Currently, each pack of cigarettes has to have a fee stamp and the method of stamping is under consideration for alcoholic beverages as well. Value added tax system is misused for tax crimes as well. According this tax law the financial office (i.e., the state) has to refund the VAT to the exporter. Therefore, fictional exports, or overvalued exports, can generate substantial cash. 
All these mentioned crimes require at least passive cooperation of tax authority or custom authority, which is also a part of the fiscal administration. Quite common are also cases of imports with declared low value to reduce the import duty. The most prevalent cases were imports of used cars where the declared custom value was estimated to be only one tenth of the real value.

\subsection{Licensing}

The licensing is used to regulate the access mainly in areas of telecommunications, radio and television broadcasting, insurance and finance, foreign trade with selected commodities (armaments or goods with existing import quotas), and mining. The procedure of licensing should be transparent and, if possible, single-criteria, or the selecting criteria of multi-criteria tender should be at least integral part of the license provided. There are well-known cases from the past where the license procedure resulted in a suspicious conclusion.

\section{$\underline{\text { Banking and Finance }}$}

At the beginning of the transition the state allowed new entry and it was very easy to receive a banking license. All new small banks got into liquidity problems or were tunneled and had to merge or went bankrupt. The state responded on by the freeze of issuing new licenses instead of more professional and prudent regulation.

The investment funds, newly established during the voucher privatization, became, with several exceptions, synonym for asset stripping and abuse of small shareholders. There existed no effective regulation of investment funds. The complete lack of stock market regulation even speeded up the process of dishonesty through obvious price manipulation. This is also a reason why there is a strong opposition against the existence of a compulsory private pension fund scheme, although the pay-as-you-go pension system is getting into a huge deficit and the prospects look blandly.

The situation on the insurance market is more optimistic despite the fact that the regulation is quite similar to that used for investment funds. So far only one insurance company went bankrupt. On the other hand, the market is still not fully open and licensing is limited.

\section{$\underline{\text { Telecommunications }}$}

The monopolist fixed line provider has its exclusive rights granted till January $1^{\text {st }}, 2001$. Then new licenses will be issued. The reason is that in the past the fixed line network required enormous investments. Therefore during privatization process a strategic partner was selected and in exchange for commitment to build up and modernize the network such exclusivity was granted. As an experiment, in several regions small local companies were licensed to provide the fixed lines, however the incumbent controls 99.9\% of all lines (OECD, 1999).

The exclusivity right even on building the fixed end-line network was questioned in the 
past since it may slow down the speed of wiring the whole country. However, no direct evidence was found although the case was reopened by the press during the investigation of illegal sponsoring of political parties.

In 1999 a third license for mobile telephony (GSM) provider was granted. Although the license was based on multi-criteria choice, certain promises are not part of the license conditions. Moreover, the winning pricing scheme offered in the tender is handicapped by additional disadvantageous conditions, like cash deposits or long-term interminable contracts.

\section{$\underline{\text { Radio and TV Broadcasting }}$}

Almost a classical example of high-level lobbying is the case of free terrestrial license available and granted. The original tender involved many criteria. The license was granted to the firm that offered low price and a program of intellectually higher standards than the (state) public TV broadcast. Once the license was granted, the law was changed in a way that the program composition is not a part of the license and the TV company became highly commercialized. Quite recently, an open fight for the complete control of this highly profitable firm started between the Czech license holder and foreign investor. Fortunately, there exists a sufficient amount of radio frequencies to grant enough licenses to prevent the above situation in radio broadcasting.

\subsection{Public Tenders}

Most cases of corruption that are disclosed in the media are connected with public tenders both on the state and municipal levels. Pre-selection of the prospective supplier is one of the most cited flaws. The selection of the pre-selected firm to sign a contract with is done by the means of custom-made conditions in the tender, custom tailored weighting of criteria or even by changing the tender conditions during the tender process. Such non-standard behavior is highly susceptible and opens broad opportunities of corruption to materialize. The available means to disclose a possible manipulation in the aforementioned schemes are quite limited.

Such a behavior during transition is in line with the exposition of Acemoglu and Verdier (2000) who argue that room for corruption is created by transferring resources from one party to another by government interventions. As corruption often undermines the purpose of the intervention, government tries to prevent it. By doing so it may create rents for bureaucrats, induce a misallocation of resources, and increase the size of the bureaucracy. Since preventing all corruption is excessively costly, second-best intervention may involve a certain fraction of bureaucrats accepting bribes. Moreover, Stiglitz (1999) argues that privatization created an opportunity to collect all expected future bribes in their discounted value at the time of privatization.

Public tenders that lead to public investments may have a negative economic impact not only due to corruption associated costs. Equally important is an impact on economy in general. Tanzi and Davoodi (1997) argue that corruption, particularly political or "grand" corruption, 
distorts the entire decision-making process connected with public investment projects. The degree of distortions is higher with weaker auditing institutions. They presented evidence from various countries that higher corruption is associated with higher public investment, lower government revenues, lower expenditures on operations and maintenance, and lower quality of public infrastructure. The evidence also shows that corruption increases public investment while reducing its productivity. These are five channels through which corruption lowers growth. These findings are supported by Mauro (1995) who investigated impact of subjective indices of corruption on economic growth and found supportive evidence that corruption lowers investment, thereby lowers economic growth. Therefore, in countries with high corruption, very high public sector investments should be evaluated with caution. Since the total aggregate investment to GDP ratio in the Czech Republic is one of the highest among the CEE countries (CESTAT, 1999), the argument made by Mauro could be applied for the Czech Republic as well.

\subsection{Monopoly Regulation}

As in the cases of public tenders and licensing, the state uses chiefly discretion to regulate the monopolies (Lizal, 2000; Kočenda and Čábelka, 1999). In addition, there exists no independent regulator or regulatory office. Although the existing regulatory institutions are formally independent, they are financed by and subordinated to the founding (supervisory) ministry. According to the law and existing regulations, any disputes should be settled either by the ministry or by the regulatory office. Such an institutional arrangement will have to be abolished with the accession to the EU.

In most of the network industries the state controls the majority stake in the utilities companies (Kočenda, 1999). On the other hand, the state should behave as an independent regulator, which creates an obvious incentive problem. Such a problem cannot be solved independently on the state. Of course, absence of clear rules opens up the space for higher level corruption, although there are no proved cases. In addition, almost every monopolistic provider has to have a license. This applies not only on the large utilities but also on small local monopolies like local heat suppliers, etc.

Regulatory issues were extensively discussed by Johnson, Kaufmann, and Zoido-Lobatón (1998) who recently used cross-country regressions to explain the size of the unofficial economy in regions of Latin America, OECD countries, and transition economies in the Central and Eastern Europe (CEE). They found evidence that countries with more regulation tend to have a higher share of the unofficial economy in total GDP. They also found that higher tax burden leads to more unofficial activity and countries with more corruption tend to have a larger unofficial economy. Findings of Lacko (2000) support such a view with the evidence from the transition CEE countries. Stagnation or further increase in the size of hidden economy was experienced in the economies of the former Soviet Union, while an explicit declining tendency could be seen in more advanced transition countries. 


\subsection{State, Local and Municipal Administrations}

Earlier in the text it was mentioned that the public administration is still not perceived as a service to the general public paid by the taxpayers but as an annoying structure to be tolerated and dealt with only in the case of necessity. What is felt as a major flaw of the administration is that frequently the officials seek reasons why not to proceeds on. They search for bureaucratic mistakes and do not seek methods how to help the asking citizen to achieve his/her goal. The reasonable practice the citizens should require is different from the existing one. Currently the administration proceeds on only if the action is explicitly permitted by the existing regulation. The logic would suggest proceeding on in all cases that are not explicitly forbidden or illegal, though.

As a final illustration we provide a quite frequent, although not fully legal, practice used during renovation or construction of family houses. It is easier to start the construction work without a permit and ask the District Construction Office for a subsequent permit with a small fine to be paid. The risk of not getting the permit is extremely low and such procedure is often easier than to ask for all the permits before the beginning of the construction. Such behavior perversely saves a lot of time and, hence, money as well.

Another area of behavior apt for potential corruption concerns local authorities. The local administration, especially municipalities, often put state or municipal property as a collateral to back a third person's private loans. Such behavior is not only highly questionable but also creates opportunity for corruption to emerge. In this context, sale of a part of a National Preserve on a municipal territory serves as a flagrant example.

\subsection{Education}

A major problem of the higher education (except for the lack of finances) is a limited supply. Certain fields at universities or high schools face excessive demand, which is up to ten times the capacity. Last year, there was a case at the Law Department of a major university, where entry exams test were sold for CZK 100,000 (approx. \$3,000). No one was prosecuted or held responsible. The suggested yearly tuition is approximately ten times less than the aforementioned amount. Since the government is not in favor of introducing tuition payments at the state universities due to its possible social impact, the current situation paradoxically favors students from wealthier families. Hence, such approach is more discriminatory with respect to students from poorer families that should not be overburdened by tuition payments.

Most of the higher education is still publicly financed. The private schools also receive certain state supplement but lately the scrutiny for private school to receive such a supplement became excessively harsh. As a final effect such conduct may result in reduced government spending on education in general. ${ }^{6}$ Furthermore, the other corruption possibilities include a

\footnotetext{
${ }^{5}$ We do not mention one's high moral standards as an obvious attitude towards obtaining entry-exam answers for charge.

${ }^{6}$ Mauro (1998) argues that corruption is found to reduce government spending on education in a cross-section of
} 
preferential treatment or acceptance of selected students whose parents are able to pay extra tuition (selection of accepted students to private schools on the basis of social status) or to lobby for state finance (in case of both private and public schools).

\subsection{Health Care}

Historically, the Czechs are used to receive health care as a free service provided by the state. In the centrally planed era a limited health supply existed and such state caused the tradition of "gifts." For the service already received or to be received in the future the gifts ranged from flowers, books, coffee, and alcohol to money.

The health care is provided through a mandatory health insurance. All terms of the insurance, including premium and coverage, are determined by the state. However, the payment of health insurance is still not generally viewed as payment for the health service but rather than a tax. Health providers are not viewed as (private) businesses providing the care and being paid through the insurance companies, but as a part of the state services. This is also caused by the non-transparent system combining taxes, health insurance, and various social insurance payments. Despite the fact that people view their health as a major asset they should preserve, they do not often receive a full information on the appropriate care needed and on its fair or real price.

Aside from above mentioned, there exists a pressure form the pharmaceutical industry toward usage of more profitable drugs and there is no definition of the standard health care covered by the insurance as guaranteed by the law. The regulation is ad-hoc and usually even retrospective, sometimes punishing the provider for past efficiency.

To sum up, the patient is usually not able to:

1. recognize that the service is adequate and treatment is ethical,

2. realize that the service is too expensive or redundant, and

3. discover that the provider has charged the insurance company for non-performed services or non-supplied drugs.

On the other hand, the insurance companies are abusing their power as well. ${ }^{\square}$ They pay late and the average overdue is well above two months. There exists a silent threat of contract cancellation from the dominant insurance companies towards dependent health care providers. The providers are warned not to charge overdue interest and even manipulated to sign agreement amendments that make the contract even more disadvantageous for them. Quite recently, the newly issued regulation even worsened the situation, and medical professional society claims that the change was adopted just to prevent the financial collapse of state governed dominant health insurance company. All this can be viewed as, at least, passive corruption.

countries.

7 Association of medical doctors filed up a case against the dominant insurance company (VZP) at the Antimonopoly office. 


\subsection{Social Care}

This area concerns mainly a state unemployment policy. There exist two state unemployment policies. Active policy when the financial resources are allocated to creation of jobs, and passive policy - payment of unemployment benefits. The district labor offices govern both policies. A case study commissioned by the Ministry of Labor and Social Affaires in 1998 showed that more then 80,000 households misused the social safety net, mostly in connection with unemployment policy and welfare benefits. The Czech Republic has less than 3 millions household in total and thus the misuse occurred in about $3 \%$ of households.

There were cases in the past when people registered as unemployed and received the benefits while working part-time or full time without a legal contract in the shadow economy home or abroad. It might be questionable to which extend the officials were aware of the illegality of the claims. Other possibilities include preferring a particular candidate either to find a job or to prolong the unemployment spell.

More problematic from the corruption point of view might be the area of active policy. The rights of the district labor offices also define the possible ways of corruption. These rights include the selection of private businesses, which would receive a loan to retrain their employees, and also forgiveness of the repayment of such a loan, the selection of areas of training and selection of the re-training company. The office can also provide aid to create jobs for fresh graduates or secured jobs and provide a loan to start a private business.

\subsection{Private Businesses}

The most visible forms of corruption in private (and also semi-private) businesses involve the selection of pre-specified partners in public tenders. In the banking sector corruption is associated with provisions of loans for unreasonable or even nonexistent projects. Such practices even led to a collapse of several banks and a loss of people's deposits. Bribes associated with corruptive behavior are not marginal and thus represent substantial costs. The distressing scope of such a phenomenon was revealed in the EBRD study (EBRD, 1999), which found that 26.3\% of Czech companies admit giving bribes. Czech companies spend, on average, $4.5 \%$ of their

annual income on bribes. According to the study bribery is more prevalent in Poland and Hungary.

It would be misleading to think about corruption only in terms of extra monetary costs. Corruption in private businesses is accompanied also with spending of time of managers. Kaufmann and Shang-Jin (1999) found that firms which pay more bribes are also likely to spend more management time with bureaucrats negotiating regulations, and face higher costs of human capital. Such finding is based on data from three worldwide firm-level surveys that do not include the Czech republic. However, we assert that bribe payments, management time wasted with bureaucrats, and cost of capital may be positively correlated as well across Czech firms. 
Another perspective of corruption in private businesses is associated with hiding parts of their activities in order to reduce tax payments. Such conduct requires additional cover-up steps that involve bureaucratic corruption. We do not have a representative survey for the Czech Republic; however, we can use some proxies from other European transition countries. McMillan and Woodruff (2000) conducted a survey among the private manufacturing firms about the size of hidden unofficial activity. The firm-level regressions for the three Eastern European countries, namely Poland, Slovakia and Romania, documented that bureaucratic corruption is significantly associated with hiding output.

Hiding output is closely connected with lower ability of tax collection by state administration. In another survey Johnson, Kaufmann, McMillan, and Woodruff (2000) found the size of hidden unofficial activity to be much larger in Russia and Ukraine than in Poland, Slovakia and Romania. A comparison of cross-country averages has shown that managers in Russia and Ukraine face higher effective tax rates, worse bureaucratic corruption, greater incidence of Mafia protection and have less faith in the court system than in more advanced transition counterparts.

\section{Measures of Corruption}

In previous section we described and classified dominant forms of corruption according to different sectors of activity. Now we give a brief sketch on how such phenomenon is measured in two different ways.

There are two basic methods, how to measure the corruption. The first one is based on the counts of discovered, monitored and prosecuted cases. It uses the police statistics and statistics of Department of Justice. Its major advantage is that these are hard numbers and well-founded figures. The critical disadvantage is that it is not able to measure the latent corruption, i.e., the

undiscovered cases. It means, that in the highly corrupted environment, where any true and independent investigation is impossible, such measure can give an extremely low level of corruption. 
Table 2

Question: Did you ever give an bribe in the following sector?

\begin{tabular}{|c|c|c|}
\hline Sector & $1989 *$ & $1998 * *$ \\
\hline Personal Services (hairdresser, etc.) & 61 & 45 \\
\hline Health Service & 42 & 31 \\
\hline Purchase of Durable Goods & 39 & 2 \\
\hline Repair Services & 36 & 37 \\
\hline Car Repair Services & 30 & 17 \\
\hline State Administration (any level) & 12 & 17 \\
\hline Housing & 11 & 4 \\
\hline Funeral Services & 9 & 1 \\
\hline To Put Child in a School of Any Level & 9 & 2 \\
\hline To Get a Job or an Advantage in a Job & 6 & 7 \\
\hline
\end{tabular}

The other method of measuring tries to overcome the possible bias of the preceding method. Such method involves opinion pools, surveys, and case studies. The measures are less precise, however they more realistically reflect the situation in the country and/or particular sector. According to this principle, Transparency International constructs so-called Corruption Perception Index (CPI). CPI has a maximum value of 10, which means no corruption is perceived, while value of 0 denotes the most corruptive environment. The Czech Republic ranks in the middle of the surveyed countries, as well as Poland and Hungary. In 1998, the Czech Republic was on the $37^{\text {th }}$ place out of 85 countries surveyed while a year later the country occupied $39^{\text {th }}$ place among 99 countries. The last survey from 2000 contained 90 countries and the Czech Republic was on the 42nd place. The evolution of CPI is given in below Table 1 .

Table 3

Comparison of Corruption Perception Index Evolvement

\begin{tabular}{||l||c|c|c|c|c|c|c||}
\hline \hline Country & $1980-85$ & $1988-92$ & 1996 & 1997 & 1998 & 1999 & 2000 \\
\hline \hline Czech & \multirow{3}{*}{5.13} & \multirow{2}{*}{5.20} & 5.37 & 5.20 & 4.8 & 4.6 & 4.3 \\
Republic & & $(1.45)$ & $(0.47)$ & $(0.8)$ & $(0.8)$ & $(0.9)$ \\
\cline { 1 - 6 } Slovak & & & \multicolumn{2}{|c|}{ not evaluated } & 3.9 & 3.7 & 3.5 \\
Republic & & & \multicolumn{2}{c|}{$(1.6)$} & $(1.5)$ & $(1.2)$ \\
\hline \hline
\end{tabular}

Source: Transparency International. Note: Standard errors given in parentheses when available.

It is nothing to be happy about but according to the CPI the corruption environment in both Czech and Slovak Republics is slowly gaining strength. Current forms of corruption have the same origin in the Czech and Slovak Republics due to the common experience in the former Czechoslovakia. The existing legal systems are also quite alike, which implies that if we observe 
one type of corruption in one of the Republics, there is a high probability that the very same corruption takes place in the other. Therefore, it is plausible to take known Slovak cases as supportive evidences.

Nevertheless, one of the main reasons of the split of the former Czechoslovak Federative Republic could be attributed to the uncontrolled power of the former Slovak political representation in 1992, which wanted to pursue privatization as a form of giveaways to its political supporters. Such practices are probably the major reasons why the CPI is recently almost by one point lower for Slovakia compared to the Czech Republic, although the countries had the same starting point.

Constructing the Corruption Perception Index on a regular basis is only a small part of work that the Transparency International carries on to help fight corruption worldwide. The organization was founded in 1993 in Berlin, Germany, as an international organization to help to fight against the bribery and corruption. This non-governmental organization (NGO) aims to involve all components of civil society - state administration, the private sector, entrepreneurs, and individual citizens - in creating a multilevel system against corruption.

The National Chapter of Transparency International in the Czech Republic was founded as a civic association in June 1998. The main goals of this NGO are to facilitate the improved awareness of corruption-related problems and anti-corruption issues, to contribute to the proliferation of methods for transparent business transactions, to inform state institutions, representative groups, educational institutions and the public on how to contain corruption by perfecting legal codes, and to contribute to the development of civil society in the Czech Republic. $10^{\text {th }}$ International Anti-corruption Conference takes place in October 2001 in Prague, the capital of the Czech Republic.

\section{Anticorruption Program of the Czech Republic}

In 1997 the Government of the Czech Republic assigned the Minister of Interior to "develop a concept of offensive methods for detecting corruption in civil service" (governmental decision No. 673/97 from October 29, 1997). Later on, the current administration defined a combat against corruption as one of its priorities. The original task targeted on corruption in civil service was extended and a complex concept of a Government Program of Combating Corruption in the Czech Republic was adopted (governmental decision No. 125/99 from February 17, 1999).

The great need to adopt the above measures was due to the past development under the old centralized economic system as well as a passive approach of the state administration during the first years of transition process. Indeed, such state of affaires can be illustrated by the attitude of the public towards to governmental responsibility to take effective measures to prevent corruption. Table 4 presents results of an opinion pool related to such matter. 
Table 4

Question: Which government or governments, in your opinion, put through spreading of corruption and bribery in our country?

\begin{tabular}{|l|c|c|}
\hline \multicolumn{1}{|c|}{ Government } & Years & $\%$ \\
\hline Communist Govt.'s. in the past & $1948-1989$ & 26 \\
Federal Govt. of Mr. Čalfa & $1990-1992$ & 5 \\
Govt. (Republic) of Mr. Pithart & $1990-1992$ & 4 \\
Govt. of Mr. Klaus & $1993-1997$ & 26 \\
Govt. of Mr. Tošovský & $1997-1998$ & 0 \\
Govt. of Mr. Zeman & $1998-p r e s e n t$ & 3 \\
None & & 34 \\
\hline
\end{tabular}

It is understood that the concept of anti-corruption measures must be systematically linked with steps that deal with other social problems. Combating corruption should be conducted in an organized way with the aim to prevent any new sources of corruption to emerge. No abrupt solutions should be taken because they could be counterproductive or even threaten the economy or civil rights and freedoms instead of curbing corruption. Thus the goal of the Program of Combating Corruption is to:

1. describe the nature and objectives of combating corruption,

2. define its principal methods and means,

3. propose specific measures to be taken in respective areas,

4. define responsibilities and a time schedule, and

5. indicate the method of monitoring.

As stated earlier the priority in combating corruption is to focus on corruption in the public sector, among top civil service officials, judges, state attorneys, policemen, customs officers, officials collecting taxes, and state control institutions. Such corruption is most dangerous for stability of the country and could hinder an effective procedure against other forms of corruption and illegal activities in general. The Law on Civil Service would be a systemic measure that could complement the Program in combating corruption in this area. Such a law should define legal position and more elevated responsibilities of civil servants in aforementioned administrative bodies, including limitations imposed on their other sources of income and their disciplinary liability. While being on the agenda, the Law is still missing though.

Further targets of the Program are to deal with corruption in a private sector. Such corruption is considered to be most dangerous when it is prone to influence segments of public sector or to affect its function at national level, above all in education, health service, and media. 
The program does not plan for any new institutions to be set up or new regulations to be adopted. Existing rules and institutions should be exploited instead, as well as potential of the Czech civil society. In that respect the program does not rule out possible cooperation of government with NGOs. If the situation calls for new institutions to be established, this would be based on a principle of minimum financial support from the state budget. The program aims to increase extent of power for financial and tax authorities, as well as for police forces that administer economic crime agenda.

\subsection{Educational Program}

In order to increase awareness about corruption and ability of civil servants to fight it the government introduced an administration wide educational program involving officials from various administrative bodies. Three ministries, Ministry of Justice, Ministry of Interior, and Ministry of Education, Youth, and Sports, were assigned to work out several educational projects to increase awareness of general public as well as the ability of civil servants.

The project of national training of civil servants is focused primarily on preventing corruption to happen. Within the framework of another project, education and discussion panels for policemen, state attorneys, and judges involved in corruption cases should be organized to provide them with detailed knowledge on corruption offences and relevant counteractions. More public oriented projects call for preparation of various types of guidelines on social causes and consequences of corruption and methods of combating it, as well as development of a guideline for civilian protection against corruption. As an ultimate goal these projects are aimed to increase the public awareness of the dangers of the corruption in any form and to locate the means to investigate and stop it.

Because the governmental program to combat corruption is of a relatively recent nature there does not exist any evidence about its usefulness yet. Therefore, we are unable to evaluate it properly and matter-of-factly at this time.

\subsection{Governmental program "Clean Hands"}

Czech political parties are connected with the economy in two principal ways. First, the members or persons affiliated with political parties form parts of management and supervisory boards in the companies where the state is able to control. Second way is through "loyal" persons that benefited from earlier phases of privatization thanks to their political connections.

The campaign "Clean Hands" was audibly launched in 1998 by the current government to deal with fiscal crime and corruption. So far it has drawn an enormous amount of bad reviews from opposition parties and media for its very limited success. Legitimacy and transparency of this campaign have been questioned when it was announced that the composition of the Investigating Committee would be secret. The campaign itself produced less than 50 cases so far with the former Finance Minister being subject of one of them. It was admitted, by the Prime Minister, to be a failure and terminated in early 2000. 
In any event, the government in line with the promises made in its election program set up an inter-ministerial commission in September 1998. The major task of this body was to coordinate anti-corruption policy. Within a year the Commission was given more than 3000 cases of possible corruption to inspect. So far more than 200 complaints were filed with the prosecution. Police has inspected about 70 complaints out of these and only 20 of these have been handled in the criminal proceedings (EC, 1999).

The police refuses to prosecute a vast amount of the filed cases since the quality of the dossiers is questionable. Also sometimes there is no clear evidence whether particular behavior is prosecutable since it is not explicitly prohibited by the law although its nature might be "criminal" according the common sense.

\section{3 (Dis)improvement of legal system and proposed changes}

As the results of the new anti-corruption program are questionable and the governmental actions are lacking co-ordination, personnel and equipment resources, and appropriate legislation, the government decided to move in an easy direction. It proposed, and got approved in February 1999, an amendment to the Civil Code that increased the prison sentences for bribery from five to eight years.

Although the anti-money-laundering legislation is compatible with the internationally required standards, there are several issues that need improvement. The tasks are divided among several agencies and Ministries and there is an obvious lack of sufficient coordination. The Czech Republic has neither signed the Council of Europe Criminal Law Convention on Corruption of January 1999 nor ratified 1997 OECD Convention on Combating Bribery of Foreign Public Officials in International Business Transactions yet.

The proposed changes in the economic legislation comprise of property statements, changes in the monopoly regulation, further continuation of privatization and reform of public financing and financing of political parties. Additional changes include, for example, prescribed wire transfers above certain amount. The extent of the new legislation is still a subject of political debate since it can substantially affect the citizens' rights.

Since the Czech Republic has a minority government and all legal changes require a majority support in The Parliament, there is a limited possibility for improvement. According to the 1998 European Commission report the achieved legal changes were unsatisfactory. Similar appreciation can be found in the 1998 World Bank Country Study on the Czech Republic. The European Commission went on to cast doubt on whether the Czech Republic would be able to reach the required legal standards in time to maintain its place in the group of "fast-track" accession countries. The reports of both institutions for 1999 were more favorable.

\footnotetext{
${ }^{8}$ A case can serve as an example. A suspicious transfer of 1 billion CZK was reported by an involved foreign bank to the relevant supervising agencies with a question whether the highly unusual transfer is legal and should not be stopped. Since the permission was issued, shareholders of investment fund which management was at the same time under inspection whether it committed embezzlement suffered an unrecoverable loss.
} 
Nevertheless, the proposed changes are moving along the track of increased regulation and deterrence with high penalties leaving the current discretion nature of economic regulation. Moreover, the intended changes would make the system less transparent, more complicated and, hence, increase the scope of possible corruption. As of now, there still exist special commissions at the Ministry of Finance and at the Ministry of Social Affairs and these commissions are allowed to forgive any penalties previously imposed at their discretion. These actions are completely unregulated - which openness a space for a high-level corruption.

The governmental assessment of suggested remedies to corruption is based on old concepts of deterrence and does not involve the assessment of potential hazards introduced to the system nor the analysis of the existing ones and their elimination by a simple change. Therefore, we are quite skeptical on the positive effects; we expect that implementation of all suggested enhancements would create even more problems with corruption than solutions.

The Parliament also passed a Free Information Act. This act shall allow access to all state information with the exception of the classified data. On the other hand, the current practice is that the bureaucracy is asking excessive "processing" fees to prevent the reveal of the information.

In the summer of 1988 and 1989 the Institute of Business Research performed studies measuring the gray economy of the inefficient socialist society at that time. GfK-Praha, Ltd obtained the similar sets of data in 1998. A comparative analysis of two time-separated data sets suggested interesting findings that instances of corrupt behavior are declining. The Transparency International (1999) published the detailed comparison in the analysis "The State of Corruption after Ten Years". Despite such findings, the area of (government) clerical services have become the most corruptible institutional environment in the eyes of Czech citizens.

However, we should not be overly optimistic because, as the report states: "The transformation of corruption from the sphere of general services and sales to state clerical services, together with the socially differentiated nature of the evaluation of the necessity of bribery, signals a change in the social function of corruption. Earlier, corruption primarily assured a better level of services and a supply of shortage goods. Today, a category of people is crystallizing for whom corruption is a working tool necessary for professional success. The current common trend is towards the concentration of corruption in the state administration and the creation of a group of people whose existence is strongly dependent on corruption."

\section{Concluding Remarks}

It is widely acknowledged that corruption has negative impact on economy and society, however, it is very difficult to measure such impact as well as an extent of corruption itself. Transition process in the Central and Eastern Europe (CEE) has uncovered very nutritious soil for corruption to flourish. After formally abandoning a centralized economic system the CEE 
countries boarded the transformation process towards the market system. Rich agenda of tasks to perform general overhaul of society and economy further enhanced environment where people, being only humble humans, have took opportunity that corruption offers. Consequently, appropriate steps had to be taken against such behavior.

We attempted to document the state of corruption in the Czech republic and the measures introduced to fight it. We divided sectors of society and economy into four groups according to their importance in the prevention of a corruption and a consequential hazard to the society. We provided possible means of corruption but there was little of hard evidence in a form of the criminal prosecution. Therefore, we included major known cases as illustrative examples where possible. We also described the governmental concept of anti-corruption measures and outlined achievements and failures of such a program.

The overall impression favors persistent presence of corruption within the society and economy in the Czech Republic. Numerous comparative studies, however, suggest that corruption is more prominent feature in other transition countries with economies of the former Soviet Union leading the pack. Nevertheless, the state of corruption in the country, measured by the Corruption Perception Index, presents a serious problem since the index does not improve as transition process advances. We believe that the institutional framework to prevent and fight corruption is improving, though. 


\section{REFERENCES}

Acemoglu, Daron and Thierry Verdier, (2000): "The Choice between Market Failures and Corruption," American Economic Review, 90(1), pp. 194-211.

CESTAT (1999): CESTAT Statistical Bulletin, Czech, Hungarian, Polish, Slovak, Slovenian, and Romanian Statistical Offices, various issues, Prague.

EBRD (1999): Transition Report, European Bank for Reconstruction and Development, London.

EC (1999): Accession Report on the Czech Republic, European Commission, Brussels.

Johnson, Simon, Daniel Kaufmann, John McMillan, and Christopher Woodruff, (2000): "Why do firms hide? Bribes and unofficial activity after communism," Journal of Public Economics, Amsterdam, 76(3), pp. 495-520.

Johnson, Simon, Daniel Kaufmann, and Pablo Zoido-Lobatón (1998): "Regulatory Discretion and the Unofficial Economy,” American Economic Review, 88(2), pp. 387-392.

Johnson, Simon, John McMillan, and Christopher Woodruff, (2000): "Entrepreneurs and the Ordering of Institutional Reform: Poland, Slovakia, Romania, Russia and Ukraine Compared Source," Economics of Transition, 8(1), pp. 1-36.

Kaufmann, Daniel and Shang-Jin Wei, (1999): "Does 'Grease Money' Speed Up the Wheels of Commerce?," NBER Working Paper No 7093.

Kočenda, Evžen, (1999): "Residual State Property in the Czech Republic," Eastern European Economics, 37 (5), pp. 6-35.

Kočenda, Evžen, and Štěpán Čábelka, (1999): "Liberalization in the Energy Sector: Transition and Growth," Osteuropa Wirtschaft, 44 (1), pp. 104-116.

Lacko, Maria, (2000): "Hidden economy -an unknown quantity? Comparative Analysis of Hidden Economies in Transition Countries, 1989-95," Economics of Transition, 8(1), pp. 117149

Lizal, Lubomir, (2000): “Koordinace ekonomické politiky ČR v sít’ových odvětvích a praxí EU (Coordination of the Czech Economic Policy in Network Industries with Practice in the EU),“ Finance a úvěr, 9, pp. 488-502.

Lizal, Lubomir and Jan Svejnar, (2000): "Financial Conditions and Investment during the Transition: Evidence from Czech Firms," CERGE-EI Working Paper \# 153. 
Mauro, Paolo, (1995): “Corruption and Growth,” Quarterly Journal of Economics, 110(3), pp. 681-712.

Mauro, Paolo, (1998): "Corruption and the Composition of Government Expenditure," Journal of Public Economics, 69(2), pp. 263-79.

OECD (1999): OECD Communication Outlook, OECD, Paris.

Rose-Ackerman, Susan, (1999): "Corruption and government: Causes, consequences, and reform," Cambridge University Press, Cambridge, New York and Melbourne.

Stiglitz, Joseph, (1999): "Whither Reform," Annual Bank Conference on Development Economics, Washington, DC, April 28-30, 1999.

Tanzi, Vito and Hamid Davoodi, (1997): “Corruption, Public Investment, and Growth," IMF Working Paper WP/97/139.

Turnovec, Frantisek (ed.), (1999): Czech Republic 1998, Facing Reality, CERGE UK, Prague, January.

Transparency International (1999): The State of Corruption after Ten Years. http://www.transparency.cz/english/state.html 


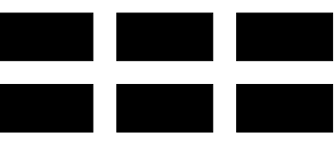

THE WILLIAM DAVIDSON INSTITUTE

AT THE UNIVERSITY OF MICHIGAN BUSINESSSCHOOL

\section{DAVIDSON INSTITUTE WORKING PAPER SERIES}

CURRENT AS OF 11/06/00

\begin{tabular}{|c|c|c|}
\hline Publication & Authors & Date of Paper \\
\hline $\begin{array}{l}\text { No. } 345 \text { Corruption and Anticorruption in the } \\
\text { Czech Republic }\end{array}$ & Lubomír Lízal and Evžen Kočenda & October 2000 \\
\hline $\begin{array}{l}\text { No. } 344 \text { The Effects of Direct Foreign } \\
\text { Investment on Domestic Firms }\end{array}$ & Jozef Konings & October 2000 \\
\hline $\begin{array}{l}\text { No. } 343 \text { On the Identification of Relative } \\
\text { Wage Rigidity Dynamics }\end{array}$ & Patrick A. Puhani & October 2000 \\
\hline $\begin{array}{l}\text { No. } 342 \text { The Determinants of Foreign Direct } \\
\text { Investment in Transition Economies }\end{array}$ & Alan A. Bevan and Saul Estrin & October 2000 \\
\hline $\begin{array}{l}\text { No. } 341 \text { The Global Spread of Stock } \\
\text { Exchanges, } 1980-1998\end{array}$ & Klaus Weber and Gerald F. Davis & October 2000 \\
\hline $\begin{array}{l}\text { No. } 340 \text { The Costs and Benefits of Euro- } \\
\text { isation in Central-Eastern Europe Before or } \\
\text { Instead of EMU Membership }\end{array}$ & D. Mario Nuti & October 2000 \\
\hline No. 339 Debt Overhang and Barter in Russia & $\begin{array}{l}\text { Sergei Guriev, Igor Makarov and Mathilde } \\
\text { Maurel }\end{array}$ & September 2000 \\
\hline $\begin{array}{l}\text { No. } 338 \text { Firm Performance and the Political } \\
\text { Economy of Corporate Governance: Survey } \\
\text { Evidence for Bulgaria, Hungary, Slovakia and } \\
\text { Slovenia }\end{array}$ & Patrick Paul Walsh and Ciara Whela & July 2000 \\
\hline No. 337 Investment and Instability & Nauro F. Campos and Jeffrey B. Nugent & May 2000 \\
\hline $\begin{array}{l}\text { No. } 336 \text { The Evolution of the Insurance } \\
\text { Sector in Central and Eastern Europe and } \\
\text { the former Soviet Union }\end{array}$ & Robert B.K. Pye & August 2000 \\
\hline $\begin{array}{l}\text { No. } 335 \text { Institutional Technology and the } \\
\text { Chains of Trust: Capital Markets and } \\
\text { Privatization in Russia and the Czech } \\
\text { Republic }\end{array}$ & Bruce Kogut and Andrew Spicer & August 2000 \\
\hline $\begin{array}{l}\text { No. } 334 \text { The Evolution of Market Integration } \\
\text { in Russia }\end{array}$ & Daniel Berkowitz and David N. DeJong & August 2000 \\
\hline $\begin{array}{l}\text { No. } 333 \text { Efficiency and Market Share in } \\
\text { Hungarian Corporate Sector }\end{array}$ & László Halpern and Gábor Kőrösi & July 2000 \\
\hline $\begin{array}{l}\text { No. } 332 \text { Search-Money-and-Barter Models of } \\
\text { Financial Stabilization }\end{array}$ & S.I. Boyarchenko and S.Z. Levendorskii & July 2000 \\
\hline $\begin{array}{l}\text { No. } 331 \text { Worker Training in a Restructuring } \\
\text { Economy: Evidence from the Russian } \\
\text { Transition }\end{array}$ & $\begin{array}{l}\text { Mark C. Berger, John S. Earle and Klara } \\
\text { Z. Sabirianova }\end{array}$ & August 2000 \\
\hline $\begin{array}{l}\text { No. 330 Economic Development in Palanpur } \\
\text { 1957-1993: A Sort of Growth }\end{array}$ & Peter Lanjouw & August 2000 \\
\hline $\begin{array}{l}\text { No. } 329 \text { Trust, Organizational Controls, } \\
\text { Knowledge Acquisition from the Foreign } \\
\text { Parents, and Performance in Vietnamese } \\
\text { International Joint Ventures }\end{array}$ & $\begin{array}{l}\text { Marjorie A. Lyles, Le Dang Doanh, and } \\
\text { Jeffrey Q. Barden }\end{array}$ & June 2000 \\
\hline $\begin{array}{l}\text { No. } 328 \text { Comparative Advertising in the } \\
\text { Global Marketplace: The Effects of Cultural } \\
\text { Orientation on Communication }\end{array}$ & $\begin{array}{l}\text { Zeynep Gürhan-Canli and Durairaj } \\
\text { Maheswaran }\end{array}$ & August 2000 \\
\hline No. 327 Post Privatization Enterprise & Morris Bornstein & July 2000 \\
\hline
\end{tabular}

Working Papers are available at:

www.wdi.bus.umich.edu 


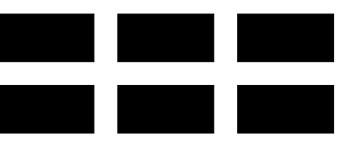

THE WILLIAM DAVIDSON INSTITUTE AT THE UNIVERSITY OF MICHIGAN BUSINESSSCHOOL

\begin{tabular}{|c|c|c|}
\hline Restructuring & & \\
\hline No. 326 Who is Afraid of Political Instability? & Nauro F. Campos and Jeffrey B. Nugent & July 2000 \\
\hline $\begin{array}{l}\text { No. } 325 \text { Business Groups, the Financial } \\
\text { Market and Modernization }\end{array}$ & Raja Kali & June 2000 \\
\hline $\begin{array}{l}\text { No. } 324 \text { Restructuring with What Success? A } \\
\text { Case Study of Russian Firms }\end{array}$ & Susan Linz & July 2000 \\
\hline $\begin{array}{l}\text { No. } 323 \text { Priorities and Sequencing in } \\
\text { Privatization: Theory and Evidence from the } \\
\text { Czech Republic }\end{array}$ & $\begin{array}{l}\text { Nandini Gupta, John C. Ham and Jan } \\
\text { Svejnar }\end{array}$ & May 2000 \\
\hline $\begin{array}{l}\text { No. } 322 \text { Liquidity, Volatility, and Equity } \\
\text { Trading Costs Across Countries and Over } \\
\text { Time }\end{array}$ & $\begin{array}{l}\text { Ian Domowitz, Jack Glen and Ananth } \\
\text { Madhavan }\end{array}$ & March 2000 \\
\hline $\begin{array}{l}\text { No. } 321 \text { Equilibrium Wage Arrears: } \\
\text { Institutional Lock-In of Contractual Failure in } \\
\text { Russia }\end{array}$ & John S. Earle and Klara Z. Sabirianova & October 2000 \\
\hline $\begin{array}{l}\text { No. } 320 \text { Rethinking Marketing Programs for } \\
\text { Emerging Markets }\end{array}$ & Niraj Dawar and Amitava Chattopadhyay & June 2000 \\
\hline $\begin{array}{l}\text { No. } 319 \text { Public Finance and Low Equilibria in } \\
\text { Transition Economies; the Role of Institutions }\end{array}$ & Daniel Daianu and Radu Vranceanu & June 2000 \\
\hline $\begin{array}{l}\text { No. } 318 \text { Some Econometric Evidence on the } \\
\text { Effectiveness of Active Labour Market } \\
\text { Programmes in East Germany }\end{array}$ & Martin Eichler and Michael Lechner & June 2000 \\
\hline $\begin{array}{l}\text { No. } 317 \text { A Model of Russia’s "Virtual } \\
\text { Economy" }\end{array}$ & R.E Ericson and B.W Ickes & May 2000 \\
\hline $\begin{array}{l}\text { No. } 316 \text { Financial Institutions, Financial } \\
\text { Contagion, and Financial Crises }\end{array}$ & Haizhou Huang and Chenggang Xu & March 2000 \\
\hline $\begin{array}{l}\text { No. } 315 \text { Privatization versus Regulation in } \\
\text { Developing Economies: The Case of West } \\
\text { African Banks }\end{array}$ & $\begin{array}{l}\text { Jean Paul Azam, Bruno Biais, and } \\
\text { Magueye Dia }\end{array}$ & February 2000 \\
\hline $\begin{array}{l}\text { No. } 314 \text { Is Life More Risky in the Open? } \\
\text { Household Risk-Coping and the Opening of } \\
\text { China's Labor Markets }\end{array}$ & John Giles & April 2000 \\
\hline $\begin{array}{l}\text { No. } 313 \text { Networks, Migration and Investment: } \\
\text { Insiders and Outsiders in Tirupur's Production } \\
\text { Cluster }\end{array}$ & Abhijit Banerjee and Kaivan Munshi & March 2000 \\
\hline $\begin{array}{l}\text { No. } 312 \text { Computational Analysis of the Impact } \\
\text { on India of the Uruguay Round and the } \\
\text { Forthcoming WTO Trade Negotiations }\end{array}$ & $\begin{array}{l}\text { Rajesh Chadha, Drusilla K. Brown, Alan } \\
\text { V. Deardorff and Robert M. Stern }\end{array}$ & March 2000 \\
\hline $\begin{array}{l}\text { No. } 311 \text { Subsidized Jobs for Unemployed } \\
\text { Workers in Slovakia }\end{array}$ & Jan. C. van Ours & May 2000 \\
\hline $\begin{array}{l}\text { No. } 310 \text { Determinants of Managerial Pay in } \\
\text { the Czech Republic }\end{array}$ & $\begin{array}{l}\text { Tor Eriksson, Jaromir Gottvald and Pavel } \\
\text { Mrazek }\end{array}$ & May 2000 \\
\hline $\begin{array}{l}\text { No. } 309 \text { The Great Human Capital } \\
\text { Reallocation: An Empirical Analysis of } \\
\text { Occupational Mobility in Transitional Russia }\end{array}$ & Klara Z. Sabirianova & October 2000 \\
\hline $\begin{array}{l}\text { No. } 308 \text { Economic Development, Legality, } \\
\text { and the Transplant Effect }\end{array}$ & $\begin{array}{l}\text { Daniel Berkowitz, Katharina Pistor, and } \\
\text { Jean-Francois Richard }\end{array}$ & February 2000 \\
\hline $\begin{array}{l}\text { No. } 307 \text { Community Participation, Teacher } \\
\text { Effort, and Educational Outcome: The Case of } \\
\text { El Salvador's EDUCO Program }\end{array}$ & Yasuyuki Sawada & November 1999 \\
\hline No. 306 Gender Wage Gap and Segregation in & Stepan Jurajda & May 2000 \\
\hline
\end{tabular}

Working Papers are available at: www.wdi.bus.umich.edu 


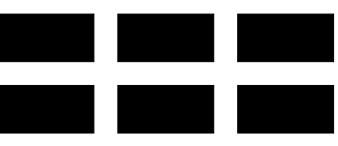

THE WILLIAM DAVIDSON INSTITUTE AT THE UNIVERSITY OF MICHIGAN BUSINESSSCHOOL

\begin{tabular}{|c|c|c|}
\hline Late Transition & & \\
\hline $\begin{array}{l}\text { No. } 305 \text { The Gender Pay Gap in the Transition } \\
\text { from Communism: Some Empirical Evidence }\end{array}$ & Andrew Newell and Barry Reilly & May 2000 \\
\hline $\begin{array}{l}\text { No. } 304 \text { Post-Unification Wage Growth in } \\
\text { East Germany }\end{array}$ & Jennifer Hunt & November 1998 \\
\hline $\begin{array}{l}\text { No. } 303 \text { How Does Privatization Affect } \\
\text { Workers? The Case of the Russian Mass } \\
\text { Privatization Program }\end{array}$ & Elizabeth Brainerd & May 2000 \\
\hline $\begin{array}{l}\text { No. } 302 \text { Liability for Past Environmental } \\
\text { Contamination and Privatization }\end{array}$ & Dietrich Earnhart & March 2000 \\
\hline No. 301 Varieties, Jobs and EU Enlargement & Tito Boeri and Joaquim Oliveira Martins & May 2000 \\
\hline No. 300 Employer Size Effects in Russia & Todd Idson & April 2000 \\
\hline $\begin{array}{l}\text { No. } 299 \text { Information Complements, } \\
\text { Substitutes, and Strategic Product Design }\end{array}$ & $\begin{array}{l}\text { Geoffrey G. Parker and Marshall W. Van } \\
\text { Alstyne }\end{array}$ & March 2000 \\
\hline $\begin{array}{l}\text { No. } 298 \text { Markets, Human Capital, and } \\
\text { Inequality: Evidence from Rural China }\end{array}$ & $\begin{array}{l}\text { Dwayne Benjamin, Loren Brandt, Paul } \\
\text { Glewwe, and Li Guo }\end{array}$ & May 2000 \\
\hline $\begin{array}{l}\text { No. } 297 \text { Corporate Governance in the Asian } \\
\text { Financial Crisis }\end{array}$ & $\begin{array}{l}\text { Simon Johnson, Peter Boone, Alasdair } \\
\text { Breach, and Eric Friedman }\end{array}$ & November 1999 \\
\hline $\begin{array}{l}\text { No. } 296 \text { Competition and Firm Performance: } \\
\text { Lessons from Russia }\end{array}$ & J. David Brown and John S. Earle & March 2000 \\
\hline $\begin{array}{l}\text { No. } 295 \text { Wage Determination in Russia: An } \\
\text { Econometric Investigation }\end{array}$ & Peter J. Luke and Mark E. Schaffer & March 2000 \\
\hline $\begin{array}{l}\text { No. 294: Can Banks Promote Enterprise } \\
\text { Restructuring?: Evidence From a Polish } \\
\text { Bank's Experience }\end{array}$ & John P. Bonin and Bozena Leven & March 2000 \\
\hline $\begin{array}{l}\text { No. 293: Why do Governments Sell Privatised } \\
\text { Companies Abroad? }\end{array}$ & $\begin{array}{l}\text { Bernardo Bortolotti, Marcella Fantini and } \\
\text { Carlo Scarpa }\end{array}$ & March 2000 \\
\hline $\begin{array}{l}\text { No. 292: Going Public in Poland: Case-by- } \\
\text { Case Privatizations, Mass Privatization and } \\
\text { Private Sector Initial Public Offerings }\end{array}$ & Wolfgang Aussenegg & December 1999 \\
\hline $\begin{array}{l}\text { No. 291: Institutional Technology and the } \\
\text { Chains of Trust: Capital Markets and } \\
\text { Privatization in Russia and the Czech } \\
\text { Republic }\end{array}$ & Bruce Kogut and Andrew Spicer & March 1999 \\
\hline $\begin{array}{l}\text { No. 290: Banking Crises and Bank Rescues: } \\
\text { The Effect of Reputation }\end{array}$ & Jenny Corbett and Janet Mitchell & January 2000 \\
\hline $\begin{array}{l}\text { No. 289: Do Active Labor Market Policies } \\
\text { Help Unemployed Workers to Find and Keep } \\
\text { Regular Jobs? }\end{array}$ & Jan C. van Ours & February 2000 \\
\hline $\begin{array}{l}\text { No. 288: Consumption Patterns of the New } \\
\text { Elite in Zimbabwe }\end{array}$ & Russell Belk & February 2000 \\
\hline $\begin{array}{l}\text { No. 287: Barter in Transition Economies: } \\
\text { Competing Explanations Confront Ukranian } \\
\text { Data }\end{array}$ & $\begin{array}{l}\text { Dalia Marin, Daniel Kaufmann and } \\
\text { Bogdan Gorochowskij }\end{array}$ & January 2000 \\
\hline $\begin{array}{l}\text { No. 286: The Quest for Pension Reform: } \\
\text { Poland's Security through Diversity }\end{array}$ & Marek Góra and Michael Rutkowski & January 2000 \\
\hline $\begin{array}{l}\text { No. 285: Disorganization and Financial } \\
\text { Collapse }\end{array}$ & Dalia Marin and Monika Schnitzer & October 1999 \\
\hline $\begin{array}{l}\text { No. 284: Coordinating Changes in M-form } \\
\text { and U-form Organizations }\end{array}$ & $\begin{array}{l}\text { Yingyi Qian, Gérard Roland and } \\
\text { Chenggang Xu }\end{array}$ & May 1999 \\
\hline No. 283: Why Russian Workers Do Not & Guido Friebel and Sergei Guriev & October 1999 \\
\hline
\end{tabular}

Working Papers are available at: www.wdi.bus.umich.edu 


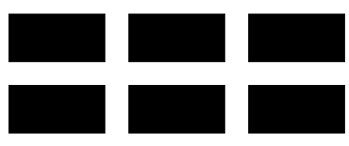

THE WILLIAM DAVIDSON INSTITUTE AT THE UNIVERSITY OF MICHIGAN BUSINESSSCHOOL

\begin{tabular}{|c|c|c|}
\hline $\begin{array}{l}\text { Move: Attachment of Workers Through In- } \\
\text { Kind Payments }\end{array}$ & & \\
\hline $\begin{array}{l}\text { No. 282: Lessons From Fiascos in Russian } \\
\text { Corporate Governance }\end{array}$ & Merritt B. Fox and Michael A. Heller & October 1999 \\
\hline $\begin{array}{l}\text { No. 281: Income Distribution and Price } \\
\text { Controls: Targeting a Social Safety Net } \\
\text { During Economic Transition }\end{array}$ & Michael Alexeev and James Leitzel & March 1999 \\
\hline $\begin{array}{l}\text { No. 280: Starting Positions, Reform Speed, } \\
\text { and Economic Outcomes in Transitioning } \\
\text { Economies }\end{array}$ & William Hallagan and Zhang Jun & January 2000 \\
\hline No. 279: The Value of Prominent Directors & Yoshiro Miwa \& J. Mark Ramseyer & October 1999 \\
\hline No. 278: The System Paradigm & János Kornai & April 1998 \\
\hline $\begin{array}{l}\text { No. 277: The Developmental Consequences of } \\
\text { Foreign Direct Investment in the Transition } \\
\text { from Socialism to Capitalism: The } \\
\text { Performance of Foreign Owned Firms in } \\
\text { Hungary }\end{array}$ & Lawrence Peter King & September 1999 \\
\hline $\begin{array}{l}\text { No. 276: Stability and Disorder: An } \\
\text { Evolutionary Analysis of Russia's Virtual } \\
\text { Economy }\end{array}$ & Clifford Gaddy and Barry W. Ickes & November 1999 \\
\hline $\begin{array}{l}\text { No. 275: Limiting Government Predation } \\
\text { Through Anonymous Banking: A Theory with } \\
\text { Evidence from China. }\end{array}$ & $\begin{array}{l}\text { Chong-En Bai, David D. Li, Yingyi Qian } \\
\text { and Yijiang Wang }\end{array}$ & July 1999 \\
\hline No. 274: Transition with Labour Supply & Tito Boeri & December 1999 \\
\hline $\begin{array}{l}\text { No. 273: Sectoral Restructuring and Labor } \\
\text { Mobility: A Comparative Look at the Czech } \\
\text { Republic }\end{array}$ & Vit Sorm and Katherine Terrell & November 1999 \\
\hline $\begin{array}{l}\text { No. 272: Published in: Journal of Comparative } \\
\text { Economics "Returns to Human Capital Under } \\
\text { the Communist Wage Grid and During the } \\
\text { Transition to a Market Economy" Vol. 27, pp. } \\
\text { 33-60 1999. }\end{array}$ & $\begin{array}{l}\text { Daniel Munich, Jan Svejnar and Katherine } \\
\text { Terrell }\end{array}$ & October 1999 \\
\hline $\begin{array}{l}\text { No. 271: Barter in Russia: Liquidity Shortage } \\
\text { Versus Lack of Restructuring }\end{array}$ & Sophie Brana and Mathilde Maurel & June 1999 \\
\hline $\begin{array}{l}\text { No. 270: Tests for Efficient Financial } \\
\text { Intermediation with Application to China }\end{array}$ & Albert Park and Kaja Sehrt & March 1999 \\
\hline $\begin{array}{l}\text { No. 269a: Russian Privatization and Corporate } \\
\text { Governance: What Went Wrong? }\end{array}$ & $\begin{array}{l}\text { Bernard Black, Reinier Kraakman and } \\
\text { Anna Tarassova }\end{array}$ & May 2000 \\
\hline $\begin{array}{l}\text { No. 269: Russian Privatization and Corporate } \\
\text { Governance: What Went Wrong? }\end{array}$ & $\begin{array}{l}\text { Bernard Black, Reinier Kraakman and } \\
\text { Anna Tarassova }\end{array}$ & September 1999 \\
\hline $\begin{array}{l}\text { No. 268: Are Russians Really Ready for } \\
\text { Capitalism? }\end{array}$ & Susan Linz & September 1999 \\
\hline $\begin{array}{l}\text { No. 267: Do Stock Markets Promote } \\
\text { Economic Growth? }\end{array}$ & $\begin{array}{l}\text { Randall K. Filer, Jan Hanousek and Nauro } \\
\text { Campos }\end{array}$ & September 1999 \\
\hline $\begin{array}{l}\text { No. 266: Objectivity, Proximity and } \\
\text { Adaptability in Corporate Governance }\end{array}$ & Arnoud W.A Boot and Jonathan R. Macey & September 1999 \\
\hline $\begin{array}{l}\text { No. 265: When the Future is not What it Used } \\
\text { to Be: Lessons from the Western European } \\
\text { Experience to Forecasting Education and } \\
\text { Training in Transitional Economies }\end{array}$ & $\begin{array}{l}\text { Nauro F. Campos, Gerard Hughes, Stepan } \\
\text { Jurajda, and Daniel Munich }\end{array}$ & September 1999 \\
\hline
\end{tabular}

Working Papers are available at: www.wdi.bus.umich.edu 


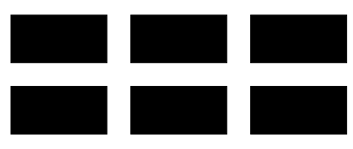

THE WILLIAM DAVIDSON INSTITUTE

AT THE UNIVERSITY OF MICHIGAN BUSINESSSCHOOL

\begin{tabular}{|c|c|c|}
\hline $\begin{array}{l}\text { No. 264: The Institutional Foundation of } \\
\text { Foreign-Invested Enterprises (FIEs) in China }\end{array}$ & Yasheng Huang & September 1999 \\
\hline $\begin{array}{l}\text { No. 263: The Changing Corporate Governance } \\
\text { Paradigm: Implications for Transition and } \\
\text { Developing Countries }\end{array}$ & $\begin{array}{l}\text { Erik Berglof and Ernst-Ludwig von } \\
\text { Thadden }\end{array}$ & June 1999 \\
\hline No. 262: Law Enforcement and Transition & Gerard Roland and Thierry Verdier & May 1999 \\
\hline $\begin{array}{l}\text { No. 261: Soft Budget Constraints, Pecuniary } \\
\text { Externality, and the Dual Track System }\end{array}$ & Jiahua Che & June 2000 \\
\hline $\begin{array}{l}\text { No. 260: Missing Market in Labor Quality: } \\
\text { The Role of Quality Markets in Transition }\end{array}$ & Gary H. Jefferson & July 1999 \\
\hline $\begin{array}{l}\text { No. 259: Do Corporate Global Environmental } \\
\text { Standards in Emerging Markets Create or } \\
\text { Destroy Market Value }\end{array}$ & $\begin{array}{l}\text { Glen Dowell, Stuart Hart and Bernard } \\
\text { Yeung }\end{array}$ & June 1999 \\
\hline $\begin{array}{l}\text { No. 258: Public Training and Outflows from } \\
\text { Unemployment }\end{array}$ & Patrick A. Puhani & June 1999 \\
\hline $\begin{array}{l}\text { No. 257: Ownership Versus Environment: } \\
\text { Why are Public Sector Firms Inefficient? }\end{array}$ & Ann P. Bartel and Ann E. Harrison & June 1999 \\
\hline $\begin{array}{l}\text { No. 256: Taxation and Evasion in the Presence } \\
\text { of Exortion by Organized Crime }\end{array}$ & $\begin{array}{l}\text { Michael Alexeev, Eckhard Janeba and } \\
\text { Stefan Osborne }\end{array}$ & November 1999 \\
\hline $\begin{array}{l}\text { No. 255: Revisiting Hungary's Bankruptcy } \\
\text { Episode }\end{array}$ & John P. Bonin and Mark E. Schaffer & September 1999 \\
\hline $\begin{array}{l}\text { No. 254: FDI in Emerging Markets: A Home- } \\
\text { Country View }\end{array}$ & Marina v.N Whitman & June 1999 \\
\hline $\begin{array}{l}\text { No. 253: The Asian Financial Crisis: What } \\
\text { Happened, and What is to be Done }\end{array}$ & Jeffrey D. Sachs and Wing Thye Woo & January 1999 \\
\hline $\begin{array}{l}\text { No. 252: Organizational Law as Asset } \\
\text { Partitioning }\end{array}$ & Henry Hansmann and Reinier Kraakman & September 1999 \\
\hline $\begin{array}{l}\text { No. 251: Consumer Behavior Research in } \\
\text { Emerging Consumer Markets: the Case of the } \\
\text { Optimum Stimulation Level in South Africa }\end{array}$ & $\begin{array}{l}\text { Jan-Benedict E. M. Steenkamp and Steven } \\
\text { M. Burgess }\end{array}$ & September 1999 \\
\hline $\begin{array}{l}\text { No. 250: Property Rights Formation and the } \\
\text { Organization of Exchange and Production in } \\
\text { Rural China }\end{array}$ & $\begin{array}{l}\text { Matthew A. Turner, Loren Brandt, and } \\
\text { Scott Rozelle }\end{array}$ & July 1998 \\
\hline $\begin{array}{l}\text { No. 249: Impacts of the Indonesian Economic } \\
\text { Crisis: Price Changes and the Poor }\end{array}$ & $\begin{array}{l}\text { James Levinsohn, Steven Berry, and Jed } \\
\text { Friedman }\end{array}$ & June 1999 \\
\hline $\begin{array}{l}\text { No. 248: Internal Barriers in the Transition of } \\
\text { Enterprises from Central Plan to Market }\end{array}$ & Charalambos Vlachoutsicos & July 1999 \\
\hline $\begin{array}{l}\text { No. 247: Spillovers from Multinationals in } \\
\text { Developing Countries: the Mechanisms at } \\
\text { Work }\end{array}$ & Richard E. Caves & June 1999 \\
\hline $\begin{array}{l}\text { No. 246: Dynamism and Inertia on the } \\
\text { Russian Labour Market: A Model of } \\
\text { Segmentation }\end{array}$ & $\begin{array}{l}\text { Irena Grosfeld, Claudia Senik-Leygonie, } \\
\text { Thierry Verdier, Stanislav Kolenikov and } \\
\text { Elena Paltseva }\end{array}$ & May 1999 \\
\hline $\begin{array}{l}\text { No. 245: Lessons from Bank Privatization in } \\
\text { Central Europe }\end{array}$ & John Bonin and Paul Wachtel & May 1999 \\
\hline $\begin{array}{l}\text { No. 244: Nominal-Real Tradeoffs and the } \\
\text { Effects of Monetary Policy: the Romanian } \\
\text { Experience }\end{array}$ & Christian Popa & December 1998 \\
\hline $\begin{array}{l}\text { No. 243: Privatization, Political Risk and } \\
\text { Stock Market Development in Emerging } \\
\text { Economies }\end{array}$ & Enrico C. Perotti and Pieter van Oijen & March 1999 \\
\hline No. 242: Investment Financing in Russian & Enrico C. Perotti and Stanislav Gelfer & October 1998 \\
\hline
\end{tabular}

Working Papers are available at:

www.wdi.bus.umich.edu 


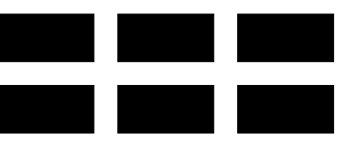

THE WILLIAM DAVIDSON INSTITUTE AT THE UNIVERSITY OF MICHIGAN BUSINESSSCHOOL

\begin{tabular}{|c|c|c|}
\hline Financial-Industrial Groups & & \\
\hline $\begin{array}{l}\text { No. 241: Can governments maintain hard } \\
\text { budget constraints? Bank lending and } \\
\text { financial isolation in Romania }\end{array}$ & $\begin{array}{l}\text { Octavian Carare, Constantijn Claessens, } \\
\text { Enrico C. Perotti }\end{array}$ & January 1999 \\
\hline $\begin{array}{l}\text { No. 240: Democratic Institutions and } \\
\text { Economic Reform: the Polish Case }\end{array}$ & $\begin{array}{l}\text { John E. Jackson, Jacek Klich, and } \\
\text { Krystyna Poznanska }\end{array}$ & April 1998 \\
\hline $\begin{array}{l}\text { No. 239: A Longitudinal Study of IJV } \\
\text { Performance in Eastern Europe }\end{array}$ & Keith D. Brouthers and Gary Bamossy & June 1999 \\
\hline $\begin{array}{l}\text { No. 238: Published in: Journal of Business } \\
\text { Venturing, "Firm Creation and Economic } \\
\text { Transitions" Vol. 14, Iss. 5,6 Sep/Nov 1999, } \\
\text { pp. 427-450. }\end{array}$ & $\begin{array}{l}\text { John E. Jackson, Jacek Klich, Krystyna } \\
\text { Poznanska }\end{array}$ & July 1998 \\
\hline $\begin{array}{l}\text { No. 237: Analysis of Entrepreneurial Attitudes } \\
\text { in Poland }\end{array}$ & $\begin{array}{l}\text { John E. Jackson and Aleksander S. } \\
\text { Marcinkowski }\end{array}$ & March 1997 \\
\hline $\begin{array}{l}\text { No. 236: Investment and Finance in De Novo } \\
\text { Private Firms: Empirical Results from the } \\
\text { Czech Republic, Hungary, and Poland }\end{array}$ & $\begin{array}{l}\text { Andrzej Bratkowski, Irena Grosfeld, Jacek } \\
\text { Rostowski }\end{array}$ & April 1999 \\
\hline $\begin{array}{l}\text { No. 235: Does a Soft Macroeconomic } \\
\text { Environment Induce Restructuring on the } \\
\text { Microeconomic Level during the Transition } \\
\text { Period? Evidence from Investment Behavior } \\
\text { of Czech Enterprises }\end{array}$ & Lubomír Lízal & June 1999 \\
\hline $\begin{array}{l}\text { No. 234: Banking Reform in China: Gradually } \\
\text { Strengthening Pillar or Fragile Reed? }\end{array}$ & John Bonin & June 1999 \\
\hline $\begin{array}{l}\text { No. 233: Theories of Soft Budget Constraints } \\
\text { and the Analysis of Banking Crises }\end{array}$ & Janet Mitchell & March 1999 \\
\hline $\begin{array}{l}\text { No. 232: Unemployment Risk, Precautionary } \\
\text { Savings, and Moonlighting in Russia }\end{array}$ & $\begin{array}{l}\text { Alessandra Guariglia and Byung-Yeon } \\
\text { Kim }\end{array}$ & June 1999 \\
\hline $\begin{array}{l}\text { No. 231: Investing in Turbulent Times: The } \\
\text { Investment Behavior of Polish Firms in the } \\
\text { Transition }\end{array}$ & $\begin{array}{l}\text { Josef C. Brada, Arthur E. King, and Chia- } \\
\text { Ying Ma }\end{array}$ & April 1999 \\
\hline $\begin{array}{l}\text { No. 230: The End of Moderate Inflation in } \\
\text { Three Transition Economies? }\end{array}$ & Josef C. Brada and Ali M. Kutan & April 1999 \\
\hline $\begin{array}{l}\text { No. 229: Back to the Future: The Growth } \\
\text { Prospects of Transition Economies } \\
\text { Reconsidered }\end{array}$ & Nauro F. Campos & April 1999 \\
\hline $\begin{array}{l}\text { No. 228: The Enterprise Isolation Program in } \\
\text { Russia }\end{array}$ & Simeon Djankov & April 1999 \\
\hline $\begin{array}{l}\text { No. 227: Published in: Journal of Comparative } \\
\text { Economics, "Ownership Concentration and } \\
\text { Corporate Performance in the Czech } \\
\text { Republic" 27(3), September 1999, pp. 498- } \\
\text { 513. }\end{array}$ & Stijn Claessens and Simeon Djankov & April 1999 \\
\hline $\begin{array}{l}\text { No. 226: Unemployment Benefit Entitlement } \\
\text { and Training Effects in Poland during } \\
\text { Transition }\end{array}$ & Patrick A. Puhani & March 1999 \\
\hline $\begin{array}{l}\text { No. 225: Transition at Whirlpool-Tatramat: } \\
\text { Case Studies }\end{array}$ & Hans Brechbuhl and Sonia Ferencikova & March 1999 \\
\hline $\begin{array}{l}\text { No. 224: Measuring Progress in Transition } \\
\text { and Towards EU Accession: A Comparison } \\
\text { of Manufacturing Firms in Poland, Romania, } \\
\text { and Spain }\end{array}$ & $\begin{array}{l}\text { Wendy Carlin, Saul Estrin, and Mark } \\
\text { Schaffer }\end{array}$ & March 1999 \\
\hline
\end{tabular}

Working Papers are available at: www.wdi.bus.umich.edu 


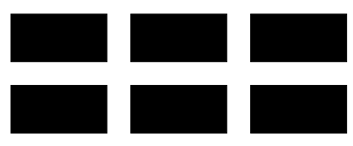

THE WILLIAM DAVIDSON INSTITUTE AT THE UNIVERSITY OF MICHIGAN BUSINESSSCHOOL

\begin{tabular}{|c|c|c|}
\hline $\begin{array}{l}\text { No. 223: Product Market Competition in } \\
\text { Transition Economies: Increasing Varieties } \\
\text { and Consumer Loyalty }\end{array}$ & Mitsutoshi M. Adachi & March 1999 \\
\hline $\begin{array}{l}\text { No. 222: Opaque Markets and Rapid Growth: } \\
\text { the Superiority of Bank-Centered Financial } \\
\text { Systems for Developing Nations }\end{array}$ & Rodney Wallace & July 1999 \\
\hline $\begin{array}{l}\text { No. 221: Technology Spillovers through } \\
\text { Foreign Direct Investment }\end{array}$ & Yuko Kinoshita & January 1999 \\
\hline $\begin{array}{l}\text { No. 220: Managerial, Expertise and Team } \\
\text { Centered Forms of Organizing: A Cross- } \\
\text { Cultural Exploration of Independence in } \\
\text { Engineering Work }\end{array}$ & Leslie Perlow & January 1999 \\
\hline $\begin{array}{l}\text { No. 219: Household Structure and Labor } \\
\text { Demand in Agriculture: Testing for } \\
\text { Separability in Rural China }\end{array}$ & Audra J. Bowlus and Terry Sicular & January 1999 \\
\hline $\begin{array}{l}\text { No. 218: Competing Strategies of FDI and } \\
\text { Technology Transfer to China: American and } \\
\text { Japanese Firms }\end{array}$ & W. Mark Fruin and Penelope Prime & January 1999 \\
\hline $\begin{array}{l}\text { No. } 217 \text { Published in: Journal of Comparative } \\
\text { Economics, "Returns to Mobility in the } \\
\text { Transition to a Market Economy" Vol. 27, No. } \\
\text { 1, March 1999, pp. 4- }\end{array}$ & Tito Boeri and Christopher J. Flinn & January 1999 \\
\hline $\begin{array}{l}\text { No. } 216 \text { Published in: Journal of Comparative } \\
\text { Economics, "Labor Market Policies and } \\
\text { Unemployment in the Czech Republic." Vol. } \\
\text { 27, No. 1, March 1999, pp. 33-60. }\end{array}$ & Katherine Terrell and Vit Sorm & November 1998 \\
\hline $\begin{array}{l}\text { No. } 215 \text { Published in: Journal of Comparative } \\
\text { Economics, "Active Labor Market Policies in } \\
\text { Poland: Human Capital Enhancement, } \\
\text { Stigmatization or Benefit Churning?" Vol. 27, } \\
\text { No. 1, March 1999, pp. 61- }\end{array}$ & $\begin{array}{l}\text { Jochen Kluve, Hartmut Lehmann, and } \\
\text { Christoph M. Schmidt }\end{array}$ & December 1998 \\
\hline $\begin{array}{l}\text { No. } 214 \text { Published in: Journal of Comparative } \\
\text { Economics, "Does the Slovenian Public Work } \\
\text { Program Increase Participants' Chances to } \\
\text { Find a Job?" Vol. 27, No.1, March 1999, pp. } \\
\text { 113- }\end{array}$ & Milan Vodopivec & December 1998 \\
\hline $\begin{array}{l}\text { No. } 213 \text { Published in: Journal of Comparative } \\
\text { Economics, "Effects of Active Labor Market } \\
\text { Programs on the Transition Rate from } \\
\text { Unemployment into Regular Jobs in the } \\
\text { Slovak Republic." Vol. 27, No. 1, March } \\
\text { 1999, pp. 90- }\end{array}$ & Martina Lubyova and Jan C. van Ours & December 1998 \\
\hline $\begin{array}{l}\text { No. 212: The Marketing System in Bulgarian } \\
\text { Livestock Production - The Present State and } \\
\text { Evolutionary Processes During the Period of } \\
\text { Economic Transition }\end{array}$ & Yordan Staykov, Team Leader & October 1998 \\
\hline $\begin{array}{l}\text { No. 211: Bankruptcy Experience in Hungary } \\
\text { and the Czech Republic }\end{array}$ & Janet Mitchell & October 1998 \\
\hline $\begin{array}{l}\text { No 210: Values, Optimum Stimulation Levels } \\
\text { and Brand Loyalty: New Scales in New } \\
\text { Populations }\end{array}$ & Steven M. Burgess and Mari Harris & September 1998 \\
\hline No. 209: Inherited Wealth, Corporate Control & Randall K. Morck, David A. Stangeland, & September 1998 \\
\hline
\end{tabular}

Working Papers are available at: www.wdi.bus.umich.edu 


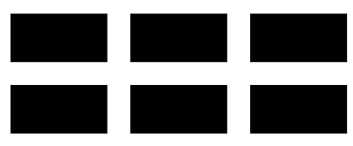

THE WILLIAM DAVIDSON INSTITUTE AT THE UNIVERSITY OF MICHIGAN BUSINESSSCHOOL

\begin{tabular}{|c|c|c|}
\hline and Economic Growth & and Bernard Yeung & \\
\hline $\begin{array}{l}\text { No. 208: A Cultural Analysis of Homosocial } \\
\text { Reproduction and Contesting Claims to } \\
\text { Competence in Transitional Firms }\end{array}$ & Michael D. Kennedy & July 1998 \\
\hline $\begin{array}{l}\text { No. 207: From Survival to Success: The } \\
\text { Journey of Corporate Transformation at Haier. } \\
\text { Forthcoming in Teaching the Dinosaurs to } \\
\text { Dance: Organizational Change in Transition } \\
\text { Economies ed. Daniel Denison. }\end{array}$ & Arthur Yeung and Kenneth DeWoskin & July 1998 \\
\hline $\begin{array}{l}\text { No. 206: Why Do People Work If They Are } \\
\text { Not Paid? An Example from Eastern Europe. } \\
\text { Forthcoming in Teaching the Dinosaurs to } \\
\text { Dance: Organizational Change in Transition } \\
\text { Economies ed. Daniel Denison. }\end{array}$ & Irina L. Zinovieva & May 1998 \\
\hline $\begin{array}{l}\text { No. 205: Firm Ownership and Work } \\
\text { Motivation in Bulgaria and Hungary: An } \\
\text { Empirical Study of the Transition in the Mid- } \\
\text { 1990s. Forthcoming in Teaching the } \\
\text { Dinosaurs to Dance: Organizational Change in } \\
\text { Transition Economies ed. Daniel Denison. }\end{array}$ & $\begin{array}{l}\text { Robert A. Roe, Irina L. Zinovieva, } \\
\text { Elizabeth Dienes, and Laurens A. ten Horn }\end{array}$ & May 1998 \\
\hline $\begin{array}{l}\text { No. 204: Human Resource Management in the } \\
\text { Restructuring of Chinese Joint Ventures. } \\
\text { Forthcoming in Teaching the Dinosaurs to } \\
\text { Dance: Organizational Change in Transition } \\
\text { Economies ed. Daniel Denison. }\end{array}$ & Nandani Lynton & April 1998 \\
\hline $\begin{array}{l}\text { No. 203: Emergent Compensation Strategies } \\
\text { in Post-Socialist Poland: Understanding the } \\
\text { Cognitive Underpinnings of Management } \\
\text { Practices in a Transition Economy. } \\
\text { Forthcoming in Teaching the Dinosaurs to } \\
\text { Dance: Organizational Change in Transition } \\
\text { Economies ed. Daniel Denison. }\end{array}$ & Marc Weinstein & March 1998 \\
\hline $\begin{array}{l}\text { No. 202: Corporate Transformation and } \\
\text { Organizational Learning: The People's } \\
\text { Republic of China. Forthcoming in Teaching } \\
\text { the Dinosaurs to Dance: Organizational } \\
\text { Change in Transition Economies ed. Daniel } \\
\text { Denison. }\end{array}$ & Meinolf Dierkes and Zhang Xinhua & March 1998 \\
\hline $\begin{array}{l}\text { No. 201: Foreign Direct Investment as a } \\
\text { Factor of Change: The Case of Slovakia. } \\
\text { Forthcoming in Teaching the Dinosaurs to } \\
\text { Dance: Organizational Change in Transition } \\
\text { Economies ed. Daniel Denison. }\end{array}$ & Sonia Ferencikova & February 1998 \\
\hline $\begin{array}{l}\text { No. 200: Radical versus Incremental Change: } \\
\text { The Role of Capabilities, Competition, and } \\
\text { Leaders. Forthcoming in Teaching the } \\
\text { Dinosaurs to Dance: Organizational Change in } \\
\text { Transition Economies ed. Daniel Denison. }\end{array}$ & Karen L. Newman & February 1998 \\
\hline $\begin{array}{l}\text { No. 199: The Emergence of Market Practices } \\
\text { in China's Economic Transition: Price Setting } \\
\text { Practices in Shanghai's Industrial Firms. } \\
\text { Forthcoming in Teaching the Dinosaurs to }\end{array}$ & Douglas Guthrie & February 1998 \\
\hline
\end{tabular}

Working Papers are available at: www.wdi.bus.umich.edu 


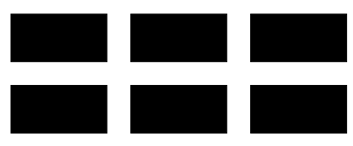

THE WILLIAM DAVIDSON INSTITUTE

AT THE UNIVERSITY OF MICHIGAN BUSINESSSCHOOL

\begin{tabular}{|c|c|c|}
\hline $\begin{array}{l}\text { Dance: Organizational Change in Transition } \\
\text { Economies ed. Daniel Denison. }\end{array}$ & & \\
\hline $\begin{array}{l}\text { No. 198: The Application of Change } \\
\text { Management Methods at Business } \\
\text { Organizations Operating in Hungary: } \\
\text { Challenges in the Business and Cultural } \\
\text { Environment and First Practical Experiences. } \\
\text { Forthcoming in Teaching the Dinosaurs to } \\
\text { Dance: Organizational Change in Transition } \\
\text { Economies ed. Daniel Denison. }\end{array}$ & Dr. János Fehér & January 1998 \\
\hline $\begin{array}{l}\text { No. 197: Organizational Changes in Russian } \\
\text { Industrial Enterprises: Mutation of Decision- } \\
\text { Making Structures and Transformations of } \\
\text { Ownership. Forthcoming in Teaching the } \\
\text { Dinosaurs to Dance: Organizational Change in } \\
\text { Transition Economies ed. Daniel Denison. }\end{array}$ & Igor B. Gurkov & January 1998 \\
\hline $\begin{array}{l}\text { No. 196: Understanding and Managing } \\
\text { Challenges to the Romanian Companies } \\
\text { during Transition. Forthcoming in Teaching } \\
\text { the Dinosaurs to Dance: Organizational } \\
\text { Change in Transition Economies ed. Daniel } \\
\text { Denison. }\end{array}$ & Dan Candea and Rodica M. Candea & January 1998 \\
\hline $\begin{array}{l}\text { No. 195: Insider Lending and Economic } \\
\text { Transition: The Structure, Function, and } \\
\text { Performance Impact of Finance Companies in } \\
\text { Chinese Business Groups. Forthcoming in } \\
\text { Teaching the Dinosaurs to Dance: } \\
\text { Organizational Change in Transition } \\
\text { Economies ed. Daniel Denison. }\end{array}$ & Lisa A. Keister & December 1997 \\
\hline $\begin{array}{l}\text { No. 194: Japanese Investment in Transitional } \\
\text { Economies: Characteristics and Performance. } \\
\text { Forthcoming in Teaching the Dinosaurs to } \\
\text { Dance: Organizational Change in Transition } \\
\text { Economies ed. Daniel Denison. }\end{array}$ & Paul W. Beamish and Andrew Delios & November 1997 \\
\hline $\begin{array}{l}\text { No. 193: Building Successful Companies in } \\
\text { Transition Economies. Forthcoming in } \\
\text { Teaching the Dinosaurs to Dance: } \\
\text { Organizational Change in Transition } \\
\text { Economies ed. Daniel Denison. }\end{array}$ & Dr. Ivan Perlaki & January 1998 \\
\hline $\begin{array}{l}\text { No. 192: Russian Communitariansim: An } \\
\text { Invisible Fist in the Transformation Process of } \\
\text { Russia. Forthcoming in Teaching the } \\
\text { Dinosaurs to Dance: Organizational Change in } \\
\text { Transition Economies ed. Daniel Denison. }\end{array}$ & Charalambos Vlachoutsicos & July 1998 \\
\hline No. 191: Teaching the Dinosaurs to Dance & Michal Cakrt & September 1997 \\
\hline $\begin{array}{l}\text { No. 190: Strategic Restructuring: Making } \\
\text { Capitalism in Post-Communist Eastern } \\
\text { Europe. Forthcoming in Teaching the } \\
\text { Dinosaurs to Dance: Organizational Change in } \\
\text { Transition Economies ed. Daniel Denison. }\end{array}$ & Lawrence P. King & September 1997 \\
\hline $\begin{array}{l}\text { No. 189: Published in: Regional Science and } \\
\text { Urban Economics, "Russia's Internal Border", }\end{array}$ & Daniel Berkowitz and David N. DeJong & July 1998 \\
\hline
\end{tabular}

Working Papers are available at: www.wdi.bus.umich.edu 


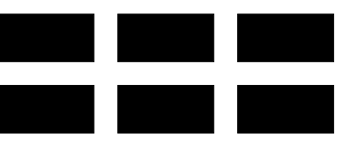

THE WILLIAM DAVIDSON INSTITUTE AT THE UNIVERSITY OF MICHIGAN BUSINESSSCHOOL

\begin{tabular}{|c|c|c|}
\hline 29 (5), September 1999. & & \\
\hline $\begin{array}{l}\text { No. 187: Corporate Structure and Performance } \\
\text { in Hungary }\end{array}$ & László Halpern and Gábor Kórsöi & July 1998 \\
\hline $\begin{array}{l}\text { No. 186: Performance of Czech Companies by } \\
\text { Ownership Structure }\end{array}$ & Andrew Weiss and Georgiy Nikitin & June 1998 \\
\hline $\begin{array}{l}\text { No. 185: Firm Performance in Bulgaria and } \\
\text { Estonia: The effects of competitive pressure, } \\
\text { financial pressure and disorganisation }\end{array}$ & Jozef Konings & July 1998 \\
\hline $\begin{array}{l}\text { No. 184: Investment and Wages during the } \\
\text { Transition: Evidence from Slovene Firms }\end{array}$ & Janez Prasnikar and Jan Svejnar & July 1998 \\
\hline $\begin{array}{l}\text { No. 183: Investment Portfolio under Soft } \\
\text { Budget: Implications for Growth, Volatility } \\
\text { and Savings }\end{array}$ & Chongen Bai and Yijiang Wang & July 1998 \\
\hline $\begin{array}{l}\text { No. 181: Delegation and Delay in Bank } \\
\text { Privatization }\end{array}$ & Loránd Ambrus-Lakatos and Ulrich Hege & July 1998 \\
\hline $\begin{array}{l}\text { No. 180: Financing Mechanisms and R\&D } \\
\text { Investment }\end{array}$ & Haizhou Huang and Chenggang $\mathrm{Xu}$ & July 1998 \\
\hline $\begin{array}{l}\text { No. 179: Organizational Culture and } \\
\text { Effectiveness: The Case of Foreign Firms in } \\
\text { Russia }\end{array}$ & Carl F. Fey and Daniel R. Denison & January 1999 \\
\hline $\begin{array}{l}\text { No. 178: Output and Unemployment } \\
\text { Dynamics in Transition }\end{array}$ & Vivek H. Dehejia and Douglas W. Dwyer & January 1998 \\
\hline $\begin{array}{l}\text { No. 177: Published in: Economics of } \\
\text { Transition,, "Bureaucracies in the Russian } \\
\text { Voucher Privatization" Vol. 8, No. 1, 2000, } \\
\text { pp. 37-57. }\end{array}$ & Guido Friebel & June 1998 \\
\hline $\begin{array}{l}\text { No. 176: Chronic Moderate Inflation in } \\
\text { Transition: The Tale of Hungary }\end{array}$ & János Vincze & June 1998 \\
\hline $\begin{array}{l}\text { No. 175: Privatisation and Market Structure in } \\
\text { a Transition Economy }\end{array}$ & John Bennett and James Maw & June 1998 \\
\hline $\begin{array}{l}\text { No. 174: Ownership and Managerial } \\
\text { Competition: Employee, Customer, or Outside } \\
\text { Ownership }\end{array}$ & Patrick Bolton and Chenggang $\mathrm{Xu}$ & June 1998 \\
\hline $\begin{array}{l}\text { No. 173: Intragovernment Procurement of } \\
\text { Local Public Good: A Theory of } \\
\text { Decentralization in Nondemocratic } \\
\text { Government }\end{array}$ & Chong-en Bai, Yu Pan and Yijiang Wang & June 1998 \\
\hline $\begin{array}{l}\text { No. 172: Political Instability and Growth in } \\
\text { Proprietary Economies }\end{array}$ & Jody Overland and Michael Spagat & August 1998 \\
\hline $\begin{array}{l}\text { No. 171: Published in Post-Communist } \\
\text { Economies, "Framework Issues in the } \\
\text { Privatization Strategies of the Czech Republic, } \\
\text { Hungary, and Poland" Vol. 11, no. 1 March } \\
\text { 1999. }\end{array}$ & Morris Bornstein & June 1998 \\
\hline $\begin{array}{l}\text { No. 170: Published in: European Journal of } \\
\text { Political Economy "Privatization, Ownership } \\
\text { Structure and Transparency: How to Measure } \\
\text { a Real Involvement of the State" 15(4), } \\
\text { November 1999, pp. 605-18. }\end{array}$ & Frantisek Turnovec & May 1998 \\
\hline $\begin{array}{l}\text { No. } 169 \text { Published in: American Economic } \\
\text { Review, "Unemployment and the Social } \\
\text { Safety Net during Transitions to a Market }\end{array}$ & $\begin{array}{l}\text { John C. Ham, Jan Svejnar, and Katherine } \\
\text { Terrell }\end{array}$ & December 1998 \\
\hline
\end{tabular}

Working Papers are available at:

www.wdi.bus.umich.edu 


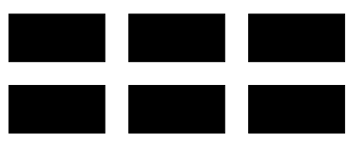

THE WILLIAM DAVIDSON INSTITUTE AT THE UNIVERSITY OF MICHIGAN BUSINESSSCHOOL

\begin{tabular}{|c|c|c|}
\hline $\begin{array}{l}\text { Economy: Evidence from Czech and Slovak } \\
\text { Men.” Vol. 88, No. 5, Dec. 1998, pp. 1117- } \\
1142 .\end{array}$ & & \\
\hline $\begin{array}{l}\text { No. 167: Voucher Privatization with } \\
\text { Investment Funds: An Institutional Analysis }\end{array}$ & David Ellerman & March 1998 \\
\hline $\begin{array}{l}\text { No. 166: Published in: Marketing Issues in } \\
\text { Transitional Economies, "Value Priorities and } \\
\text { Consumer Behavior in a Transitional } \\
\text { Economy: The Case of South Africa" ed. } \\
\text { Rajeev Batra. }\end{array}$ & $\begin{array}{l}\text { Steven M. Burgess and Jan-Benedict E.M. } \\
\text { Steenkamp }\end{array}$ & August 1998 \\
\hline $\begin{array}{l}\text { No. 164: Finance and Investment in } \\
\text { Transition: Czech Enterprises, 1993-1994 }\end{array}$ & Ronald Anderson and Chantal Kegels & September 1997 \\
\hline $\begin{array}{l}\text { No. 163: European Union Trade and } \\
\text { Investment Flows U-Shaping Industrial } \\
\text { Output in Central and Eastern Europe: Theory } \\
\text { and Evidence }\end{array}$ & Alexander Repkine and Patrick P. Walsh & April 1998 \\
\hline $\begin{array}{l}\text { No. 162: Skill Acquisition and Private Firm } \\
\text { Creation in Transition Economies }\end{array}$ & Zuzana Brixiova and Wenli Li & October 1999 \\
\hline No. 161: Corruption in Transition & Susanto Basu and David D. Li & May 1998 \\
\hline $\begin{array}{l}\text { No. 160a: Tenures that Shook the World: } \\
\text { Worker Turnover in Russia, Poland and } \\
\text { Britain }\end{array}$ & $\begin{array}{l}\text { Hartmut Lehmann and Jonathan } \\
\text { Wadsworth }\end{array}$ & November 1999 \\
\hline $\begin{array}{l}\text { No. 160: Tenures that Shook the World: } \\
\text { Worker Turnover in the Russian Federation } \\
\text { and Poland }\end{array}$ & $\begin{array}{l}\text { Hartmut Lehmann and Jonathan } \\
\text { Wadsworth }\end{array}$ & June 1998 \\
\hline $\begin{array}{l}\text { No. 159: Does Market Structure Matter? New } \\
\text { Evidence from Russia }\end{array}$ & Annette N. Brown and J. David Brown & June 1998 \\
\hline $\begin{array}{l}\text { No. 158: Structural Adjustment and Regional } \\
\text { Long Term Unemployment in Poland }\end{array}$ & Hartmut Lehmann and Patrick P. Walsh & June 1997 \\
\hline $\begin{array}{l}\text { No. 157: Baby Boom or Bust? Changing } \\
\text { Fertility in Post-Communist Czech Republic } \\
\text { and Slovakia }\end{array}$ & Robert S. Chase & April 1998 \\
\hline $\begin{array}{l}\text { No. } 156 \text { Published in: Leadership and } \\
\text { Organization Development Journal, "Leading } \\
\text { Radical Change in Transition Economies." } \\
\text { Vol. 19, No. 6, 1998, pp. 309-324. }\end{array}$ & Karen L. Newman & June 1998 \\
\hline $\begin{array}{l}\text { No. } 155 \text { Published in: Oxford Review of } \\
\text { Economic Policy, "From Theory into } \\
\text { Practice? Restructuring and Dynamism in } \\
\text { Transition Economies." Vol. 13, No. 2, } \\
\text { Summer 1997, pp. 77-105. }\end{array}$ & Wendy Carlin and Michael Landesmann & June 1997 \\
\hline $\begin{array}{l}\text { No. 154: The Model and the Reality: } \\
\text { Assessment of Vietnamese SOE Reform- } \\
\text { Implementation at the Firm Level }\end{array}$ & $\begin{array}{l}\text { Edmund Malesky, Vu Thanh Hung, Vu } \\
\text { Thi Dieu Anh, and Nancy K. Napier }\end{array}$ & July 1998 \\
\hline $\begin{array}{l}\text { No. } 153 \text { Published in: Journal of Comparative } \\
\text { Economics, "Causes of the Soft Budget } \\
\text { Constraint: Evidence on Three Explanations." } \\
\text { Vol. 26, No. 1, March 1998, pp. 104-116. }\end{array}$ & David D. Li and Minsong Liang & March 1998 \\
\hline $\begin{array}{l}\text { No. } 152 \text { Published in: Comparative Economic } \\
\text { Studies, "Enterprise Restructuring in Russia's } \\
\text { Transition Economy: Formal and Informal } \\
\text { Mechanisms." Vol. 40, No. 2, Summer 1998, }\end{array}$ & Susan J. Linz and Gary Krueger & April 1998 \\
\hline
\end{tabular}

Working Papers are available at: www.wdi.bus.umich.edu 


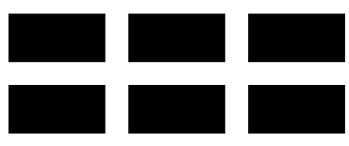

THE WILLIAM DAVIDSON INSTITUTE AT THE UNIVERSITY OF MICHIGAN BUSINESSSCHOOL

\begin{tabular}{|c|c|c|}
\hline pp. 5-52. & & \\
\hline $\begin{array}{l}\text { No. 151: Labor Productivity in Transition: A } \\
\text { Regional Analysis of Russian Industry }\end{array}$ & Susan J. Linz & May 1998 \\
\hline $\begin{array}{l}\text { No. 150: Tax Avoidance and the Allocation of } \\
\text { Credit. Forthcoming in Financial Systems in } \\
\text { Transition: The Design of Financial Systems } \\
\text { in Central Europe eds. Anna Meyendorff and } \\
\text { Anjan Thakor. }\end{array}$ & Anna Meyendorff & June 1998 \\
\hline $\begin{array}{l}\text { No. 149: Commitment, Versatility and } \\
\text { Balance: Determinants of Work Time } \\
\text { Standards and Norms in a Multi-Country } \\
\text { Study of Software Engineers }\end{array}$ & Leslie Perlow and Ron Fortgang & April 1998 \\
\hline $\begin{array}{l}\text { No. 148: Changes in Poland's Transfer } \\
\text { Payments in the 1990s: the Fate of Pensioners }\end{array}$ & Bozena Leven & June 1998 \\
\hline $\begin{array}{l}\text { No. 147: Environmental Protection and } \\
\text { Economic Development: The Case of the } \\
\text { Huaihe River Basin Cleanup Plan }\end{array}$ & $\begin{array}{l}\text { Robert Letovsky, Reze Ramazani, and } \\
\text { Debra Murphy }\end{array}$ & June 1998 \\
\hline $\begin{array}{l}\text { No. 146: Chief Executive Compensation } \\
\text { During Early Transition: Further Evidence } \\
\text { from Bulgaria }\end{array}$ & $\begin{array}{l}\text { Derek C. Jones, Takao Kato, and Jeffrey } \\
\text { Miller }\end{array}$ & June 1998 \\
\hline $\begin{array}{l}\text { No. } 145 \text { Published in: Economics of } \\
\text { Transition, "Women's Unemployment During } \\
\text { the Transition: Evidence from Czech and } \\
\text { Slovak Micro Data," Vol. 7, No. 1, May 1999, } \\
\text { pp. 47-78. }\end{array}$ & $\begin{array}{l}\text { John Ham, Jan Svejnar, and Katherine } \\
\text { Terrell }\end{array}$ & May 1998 \\
\hline No. 144: Investment and Wages in Slovenia & Janez Prasnikar & May 1998 \\
\hline $\begin{array}{l}\text { No. } 143 \text { Published in: Review of Financial } \\
\text { Studies, "Optimal Bankruptcy Laws Across } \\
\text { Different Economic Systems," 12(2), Summer } \\
\text { 1999, pgs. 347-77. }\end{array}$ & Elazar Berkovitch and Ronen Israel & March 1998 \\
\hline $\begin{array}{l}\text { No. 142: Industrial Policy and Poverty in } \\
\text { Transition Economies: Two Steps Forward or } \\
\text { One Step Back? }\end{array}$ & Susan J. Linz & March 1998 \\
\hline $\begin{array}{l}\text { No. 141: Collective Ownership and } \\
\text { Privatization of China's Village Enterprises }\end{array}$ & Suwen Pan and Albert Park & April 1998 \\
\hline $\begin{array}{l}\text { No. 140: A Comparative Look at Labor } \\
\text { Mobility in the Czech Republic: Where have } \\
\text { all the Workers Gone? }\end{array}$ & Vit Sorm and Katherine Terrell & April 1999 \\
\hline $\begin{array}{l}\text { No. 139: The Failure of the Government-Led } \\
\text { Program of Corporate Reorganization in } \\
\text { Romania }\end{array}$ & Simeon Djankov and Kosali Ilayperuma & September 1997 \\
\hline $\begin{array}{l}\text { No. 138: Ownership and Employment in } \\
\text { Russian Industry: 1992-1995 }\end{array}$ & Susan J. Linz & March 1998 \\
\hline $\begin{array}{l}\text { No. } 137 \text { Published in: Journal of Political } \\
\text { Economy, "Reform Without Losers: An } \\
\text { Interpretation of China's Dual-Track } \\
\text { Approach to Transition," Feb. 2000; Vol. 108, } \\
\text { Iss.1; pg. } 120\end{array}$ & $\begin{array}{l}\text { Lawrence J. Lau, Yingyi Qian, and Gerard } \\
\text { Roland }\end{array}$ & November 1997 \\
\hline $\begin{array}{l}\text { No. } 136 \text { Published in: European Economic } \\
\text { Review, "The Political Economy of Mass } \\
\text { Privatization and the Risk of Expropriation," } \\
\text { 44(2), February 2000, pgs. 393-421 }\end{array}$ & Klaus M. Schmidt & March 1998 \\
\hline
\end{tabular}

Working Papers are available at: www.wdi.bus.umich.edu 


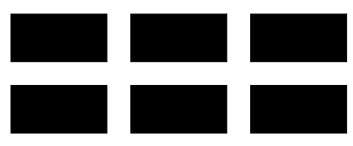

THE WILLIAM DAVIDSON INSTITUTE AT THE UNIVERSITY OF MICHIGAN BUSINESSSCHOOL

\begin{tabular}{|c|c|c|}
\hline $\begin{array}{l}\text { No. 135: Radical Organizational Change: The } \\
\text { Role of Starting Conditions, Competition, and } \\
\text { Leaders }\end{array}$ & Karen L. Newman & January 1998 \\
\hline $\begin{array}{l}\text { No. 134: To Restructure or Not to Restructure: } \\
\text { Informal Activities and Enterprise Behavior in } \\
\text { Transition }\end{array}$ & Clifford Gaddy and Barry W. Ickes & May 1998 \\
\hline $\begin{array}{l}\text { No. 133: Management 101: Behavior of Firms } \\
\text { in Transition Economies }\end{array}$ & Josef C. Brada & March 1998 \\
\hline $\begin{array}{l}\text { No. } 132 \text { Published in: Quarterly Journal of } \\
\text { Economics, "Interfirm Relationships and } \\
\text { Informal Credit in Vietnam," 114(4), Nov. } \\
\text { 1999, pgs. 1285-1320 }\end{array}$ & John McMillan and Christopher Woodruff & February 1998 \\
\hline $\begin{array}{l}\text { No. } 131 \text { Published in: Comparative Economic } \\
\text { Studies, "Will Restructuring Hungarian } \\
\text { Companies Innovate? An Investigation Based } \\
\text { on Joseph Berliner's Analysis of Innovation in } \\
\text { Soviet Industry.” Vol. 40, No. 2, Summer } \\
\text { 1998, pp. 53-74. }\end{array}$ & John B. Bonin and Istvan Abel & March 1998 \\
\hline $\begin{array}{l}\text { No. 130: Published in The American } \\
\text { Economic Review, "Changing Incentives of } \\
\text { the Chinese Bureaucracy." May, } 1998 \text {. }\end{array}$ & David D. Li & January 1998 \\
\hline $\begin{array}{l}\text { No. 129: Restructuring Investment in } \\
\text { Transition: A Model of the Enterprise } \\
\text { Decision }\end{array}$ & Richard E. Ericson & January 1998 \\
\hline $\begin{array}{l}\text { No. } 128 \text { Published in: Comparative Economic } \\
\text { Studies, “Job Rights in Russian Firms: } \\
\text { Endangered or Extinct Institutions?" Vol. 40, } \\
\text { No. 4, Winter 1998, pp. 1-32. }\end{array}$ & Susan J. Linz & January 1998 \\
\hline $\begin{array}{l}\text { No. 127: Accounting for Growth in Post- } \\
\text { Soviet Russia }\end{array}$ & Daniel Berkowitz and David N. DeJong & January 1998 \\
\hline $\begin{array}{l}\text { No. } 126 \text { Published in: Economics of } \\
\text { Transition, "From Federalism, Chinese Style, } \\
\text { to Privatization Chinese Style," 7(1), 1999, } \\
\text { pgs. 103-31 }\end{array}$ & $\begin{array}{l}\text { Yuanzheng Cao, Yingyi Qian, and Barry } \\
\text { R. Weingast }\end{array}$ & December 1997 \\
\hline $\begin{array}{l}\text { No. 125: Market Discipline in Conglomerate } \\
\text { Banks: Is an Internal Allocation of Cost of } \\
\text { Capital Necessary as Incentive Device? } \\
\text { Forthcoming in Financial Systems in } \\
\text { Transition: The Design of Financial Systems } \\
\text { in Central Europe eds. Anna Meyendorff and } \\
\text { Anjan Thakor. }\end{array}$ & Arnoud W. A. Boot and Anjolein Schmeits & November 1997 \\
\hline $\begin{array}{l}\text { No. 124: Financial Discipline in the Enterprise } \\
\text { Sector in Transition Countries: How Does } \\
\text { China Compare? }\end{array}$ & Shumei Gao and Mark E. Schaffer & February 1998 \\
\hline $\begin{array}{l}\text { No. 123: Considerations of an Emerging } \\
\text { Marketplace: Managers' Perceptions in the } \\
\text { Southern African Economic Community }\end{array}$ & Brent Chrite and David Hudson & February 1998 \\
\hline $\begin{array}{l}\text { No. 122: A Model of the Informal Economy in } \\
\text { Transition Economies }\end{array}$ & $\begin{array}{l}\text { Simon Commander and Andrei } \\
\text { Tolstopiatenko }\end{array}$ & November 1997 \\
\hline $\begin{array}{l}\text { No. 121: Local Labour Market Dynamics in } \\
\text { the Czech and Slovak Republics }\end{array}$ & Peter Huber and Andreas Worgotter & November 1997 \\
\hline No. 119: Institutional Upheaval and Company & Karen L. Newman & March 1998 \\
\hline
\end{tabular}

Working Papers are available at: www.wdi.bus.umich.edu 


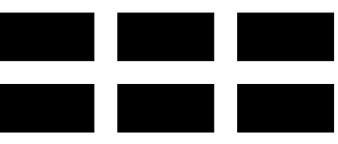

THE WILLIAM DAVIDSON INSTITUTE AT THE UNIVERSITY OF MICHIGAN BUSINESSSCHOOL

\begin{tabular}{|c|c|c|}
\hline $\begin{array}{l}\text { Transformation in Emerging Market } \\
\text { Economies }\end{array}$ & & \\
\hline $\begin{array}{l}\text { No. 118: Industrial Decline and Labor } \\
\text { Reallocation in Romania }\end{array}$ & John S. Earle & October 1997 \\
\hline $\begin{array}{l}\text { No. 117: Notes for an Essay on the Soft } \\
\text { Budget Constraint }\end{array}$ & Lorand Ambrus-Lakatos & January 1997 \\
\hline $\begin{array}{l}\text { No. 116: Labor Demand During Transition in } \\
\text { Hungary }\end{array}$ & Gabor Korosi & October 1997 \\
\hline $\begin{array}{l}\text { No. 115: Enterprise Performance and } \\
\text { Managers' Profiles }\end{array}$ & Simeon Djankov and Stijn Claessens & December 1997 \\
\hline $\begin{array}{l}\text { No. 114b Employment and Wages in } \\
\text { Enterprises under Communism and in } \\
\text { Transition: Evidence From Central Europe and } \\
\text { Russia }\end{array}$ & Swati Basu, Saul Estrin, and Jan Svejnar & April 2000 \\
\hline $\begin{array}{l}\text { No. 114: Employment and Wage Behavior of } \\
\text { Enterprises in Transitional Economies }\end{array}$ & Swati Basu, Saul Estrin, and Jan Svejnar & October 1997 \\
\hline $\begin{array}{l}\text { No. 113: Preliminary Evidence on Active } \\
\text { Labor Programs' Impact in Hungary and } \\
\text { Poland }\end{array}$ & Christopher J. O'Leary & October 1997 \\
\hline $\begin{array}{l}\text { No. 111: Unemployment Benefits and } \\
\text { Incentives in Hungary: New Evidence }\end{array}$ & Joachim Wolff & October 1997 \\
\hline $\begin{array}{l}\text { No. 110: Published in: Empirical Economics, } \\
\text { "Long-Term Unemployment, Unemployment } \\
\text { Benefits and Social Assistance: The Polish } \\
\text { Experience" Empirical-Economics; 23(1-2), } \\
\text { 1998, pages 55-85. }\end{array}$ & Marek Gora and Christoph M. Schmidt & April 1997 \\
\hline $\begin{array}{l}\text { No. } 109 \text { Published in: Industrial and Labor } \\
\text { Relations Review, "Markets for Communist } \\
\text { Human Capital: Returns to Education and } \\
\text { Experience in Post-Communist Czech } \\
\text { Republic and Slovakia." Vol. 51, No. 3, April } \\
\text { 1998, pp. 401-423. }\end{array}$ & Robert S. Chase & October 1997 \\
\hline $\begin{array}{l}\text { No. 107: The Worker-Firm Matching in the } \\
\text { Transition: (Why) Are the Czechs More } \\
\text { Successful Than Others? }\end{array}$ & $\begin{array}{l}\text { Daniel Münich, Jan Svejnar, and Katherine } \\
\text { Terrell }\end{array}$ & October 1997 \\
\hline $\begin{array}{l}\text { No. } 106 \text { Published in: Journal of Comparative } \\
\text { Economics, "Job Creation, Job Destruction } \\
\text { and Growth of Newly Established, Privatized } \\
\text { and State-Owned Enterprises in Transition } \\
\text { Economies: Survey Evidence from Bulgaria, } \\
\text { Hungary, and Romania,” Vol. 26, No.3, } \\
\text { September 1998, pp. 429-445. }\end{array}$ & Valentijn Bilsen and Jozef Konings & September 1998 \\
\hline $\begin{array}{l}\text { No. 105: Getting Behind the East-West } \\
\text { [German] Wage Differential: Theory and } \\
\text { Evidence }\end{array}$ & Michael Burda and Christoph Schmidt & May 1997 \\
\hline $\begin{array}{l}\text { No. 104: The Birth of the "Wage Curve" in } \\
\text { Hungary, 1989-95 }\end{array}$ & Gabor Kertesi and Janos Kollo & October 1997 \\
\hline $\begin{array}{l}\text { No. 103: Published in: Journal of Comparative } \\
\text { Economics, "Grime and Punishment: Job } \\
\text { Insecurity and Wage Arrears in the Russian } \\
\text { Federation" 27, 595-617 (1999). }\end{array}$ & $\begin{array}{l}\text { Hartmut Lehmann, Jonathan Wadsworth, } \\
\text { and Alessandro Acquisti }\end{array}$ & October 1997 \\
\hline No. 102: Social Networks in Transition & Lorena Barberia, Simon Johnson, and & October 1997 \\
\hline
\end{tabular}

Working Papers are available at:

www.wdi.bus.umich.edu 


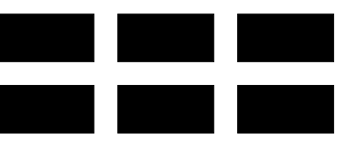

ThE WiLliam DAVIDSON InSTITUTE AT THE UNIVERSITY OF MICHIGAN BUSINESSSCHOOL

\begin{tabular}{|c|c|c|}
\hline & Daniel Kaufmann & \\
\hline $\begin{array}{l}\text { No. 101: Depreciation and Russian Corporate } \\
\text { Finance: A Pragmatic Approach to Surviving } \\
\text { the Transition }\end{array}$ & Susan J. Linz & November 1997 \\
\hline No. 100: Romanian Financial System Reform & Anna Meyendorff and Anjan V. Thakor & November 1997 \\
\hline $\begin{array}{l}\text { No. 99: Proceedings of the Conference on } \\
\text { Strategic Alliances in Transitional Economies, } \\
\text { held May 20,1997 at the Davidson Institute }\end{array}$ & Edited by Cynthia Koch & May 1997 \\
\hline $\begin{array}{l}\text { No. 98: Institutions, Strain and the } \\
\text { Underground Economy }\end{array}$ & Daniel Daianu and Lucian Albu & November 1997 \\
\hline $\begin{array}{l}\text { No. 97: Structure and Strain in Explaining } \\
\text { Inter-Enterprise Arrears }\end{array}$ & Daniel Daianu & November 1997 \\
\hline $\begin{array}{l}\text { No. 96: Resource Misallocation and Strain: } \\
\text { Explaining Shocks in Post-Command } \\
\text { Economies }\end{array}$ & Daniel Daianu & November 1997 \\
\hline $\begin{array}{l}\text { No. 95: Published in: Finance-a-Uver, "Czech } \\
\text { Money Market: Emerging Links Among } \\
\text { Interest Rates." 48(2) } 1998 \text { pp. 99-109. }\end{array}$ & Jan Hanousek and Evzen Kocenda & November 1997 \\
\hline $\begin{array}{l}\text { No. 94: Pre-Reform Industry and the } \\
\text { State Monopsony in China }\end{array}$ & Xiao-Yuan Dong and Louis Putterman & October 1997 \\
\hline $\begin{array}{l}\text { No. 93: China's State-Owned Enterprises } \\
\text { In the First Reform Decade: } \\
\text { An Analysis of a Declining Monopsony }\end{array}$ & Xiao-Yuan Dong and Louis Putterman & October 1997 \\
\hline $\begin{array}{l}\text { No. 92: Expatriate Management in the Czech } \\
\text { Republic }\end{array}$ & Richard B. Peterson & September 1997 \\
\hline $\begin{array}{l}\text { No. 91: China and the Idea of Economic } \\
\text { Reform }\end{array}$ & Thomas G. Rawski & April 1997 \\
\hline $\begin{array}{l}\text { No. } 90 \text { Published in: China Economic Review, } \\
\text { "China's State Enterprise Reform: An } \\
\text { Overseas Perspective." Vol. 8, Spring 1997, } \\
\text { pp. 89-98. }\end{array}$ & Thomas G. Rawski & July 1997 \\
\hline $\begin{array}{l}\text { No. 89: The Economic Determinants of } \\
\text { Internal Migration Flows in Russia During } \\
\text { Transition }\end{array}$ & Annette N. Brown & July 1997 \\
\hline $\begin{array}{l}\text { No. 88: Gender Wage Gaps in China's Labor } \\
\text { Market: Size, Structure, Trends }\end{array}$ & $\begin{array}{l}\text { Margaret Maurer-Fazio, Thomas G. } \\
\text { Rawski, and Wei Zhang }\end{array}$ & July 1997 \\
\hline $\begin{array}{l}\text { No. 87: Privatisation in Central and Eastern } \\
\text { Europe }\end{array}$ & Saul Estrin & June 1997 \\
\hline $\begin{array}{l}\text { No. 86: Published in : Economics of } \\
\text { Transition, "The Effect of Privatization on } \\
\text { Wealth Distribution in Russia." v. 7, no. 2, } \\
\text { 1999, pp. 449-65 }\end{array}$ & Michael Alexeev & February 1998 \\
\hline $\begin{array}{l}\text { No. 85: Was Privatization in Eastern Germany } \\
\text { a Special Case? Some Lessons from the } \\
\text { Treuhand }\end{array}$ & Uwe Siegmund & September 1997 \\
\hline No. 84: Start-ups and Transition & Daniel M. Berkowitz and David J. Cooper & September 1997 \\
\hline $\begin{array}{l}\text { No. 83: Which Enterprises (Believe They) } \\
\text { Have Soft Budgets after Mass Privatization? } \\
\text { Evidence from Mongolia }\end{array}$ & $\begin{array}{l}\text { James Anderson, Georges Korsun, and } \\
\text { Peter Murrell }\end{array}$ & October 1997 \\
\hline $\begin{array}{l}\text { No. 82: Published in: European Economic } \\
\text { Review, "Unemployment Dynamics and the } \\
\text { Restructuring of the Slovak Unemployment }\end{array}$ & Martina Lubyova and Jan C. van Ours & June 1997 \\
\hline
\end{tabular}

Working Papers are available at: www.wdi.bus.umich.edu 


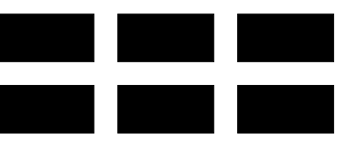

THE WILLIAM DAVIDSON INSTITUTE AT THE UNIVERSITY OF MICHIGAN BUSINESSSCHOOL

\begin{tabular}{|c|c|c|}
\hline Benefit System.” April, 1997. & & \\
\hline $\begin{array}{l}\text { No. 81: Determinants of Unemployment } \\
\text { Duration in Russia }\end{array}$ & Mark C. Foley & August 1997 \\
\hline $\begin{array}{l}\text { No. 80: The Many Faces of Information } \\
\text { Disclosure }\end{array}$ & Arnoud W.A. Boot and Anjan V. Thakor & October 1997 \\
\hline $\begin{array}{l}\text { No. 79: Published in: Journal of Finance, } \\
\text { "Foreign Speculators and Emerging Equity } \\
\text { Markets."v.22, iss. 2, 2000, pp. 565-613 }\end{array}$ & Geert Bekaert and Campbell R. Harvey & August 1997 \\
\hline $\begin{array}{l}\text { No. 78: The Relationship Between Economic } \\
\text { Factors and Equity Markets in Central Europe }\end{array}$ & Jan Hanousek and Randall K. Filer & June 1997 \\
\hline $\begin{array}{l}\text { No. } 77 \text { Published in: Economics of Transition, } \\
\text { "A Gini Decomposition Analysis of Inequality } \\
\text { in the Czech and Slovak Republics During the } \\
\text { Transition," Vol. 6, No.1, May 1998, pp. 23- } \\
\text { 46. }\end{array}$ & Thesia I. Garner and Katherine Terrell & May 1998 \\
\hline $\begin{array}{l}\text { No. 76: China's Emerging Market for Property } \\
\text { Rights: Theoretical and Empirical } \\
\text { Perspectives }\end{array}$ & Gary H. Jefferson and Thomas G. Rawski & June 1997 \\
\hline $\begin{array}{l}\text { No. 75b: Test of Permanent Income } \\
\text { Hypothesis on Czech Voucher Privatization }\end{array}$ & Jan Hanousek and Zdenek Tima & October 1997 \\
\hline $\begin{array}{l}\text { No. 74: Determinants of Performance of } \\
\text { Manufacturing Firms in Seven European } \\
\text { Transition Economies }\end{array}$ & $\begin{array}{l}\text { Stijn Claessens, Simeon Djankov, and } \\
\text { Gerhard Pohl }\end{array}$ & February 1997 \\
\hline $\begin{array}{l}\text { No. } 73 \text { Published in: Economics of Transition, } \\
\text { "The Restructuring of Large Firms in Slovak } \\
\text { Republic." Vol. 6, No. 1, May 1998, pp. 67- } \\
85\end{array}$ & Simeon Djankov and Gerhard Pohl & May 1998 \\
\hline $\begin{array}{l}\text { No. 72: Law, Relationships, and Private } \\
\text { Enforcement: Transactional Strategies of } \\
\text { Russian Enterprises }\end{array}$ & $\begin{array}{l}\text { Kathryn Hendley, Peter Murrell, and Randi } \\
\text { Ryterman }\end{array}$ & November 1998 \\
\hline $\begin{array}{l}\text { No. 71: Giving Credit Where Credit Is Due: } \\
\text { The Changing Role of Rural Financial } \\
\text { Institutions in China }\end{array}$ & Albert Park, Loren Brandt, and John Giles & March 1997 \\
\hline $\begin{array}{l}\text { No. 70: Privatization Versus Competition: } \\
\text { Changing Enterprise Behavior in Russia }\end{array}$ & John S. Earle and Saul Estrin & Spring 1997 \\
\hline $\begin{array}{l}\text { No. 69: Russian Managers under Storm: } \\
\text { Explicit Reality and Implicit Leadership } \\
\text { Theories (A Pilot Exploration) }\end{array}$ & Igor Gurkov & October 1998 \\
\hline $\begin{array}{l}\text { No. 68: The Political Economy of Central- } \\
\text { Local Relations in China: Inflation and } \\
\text { Investment Controls During the Reform Era }\end{array}$ & Yasheng Huang & Spring 1997 \\
\hline $\begin{array}{l}\text { No. 67: Between Two Coordination Failures: } \\
\text { Automotive Industrial Policy in China with a } \\
\text { Comparison to Korea }\end{array}$ & Yasheng Huang & Spring 1997 \\
\hline $\begin{array}{l}\text { No. } 66 \text { Published in: Post-Soviet Geography } \\
\text { and Economics, "Red Executives in Russia's } \\
\text { Transition Economy." Vol. 27, No. 10, } \\
\text { November 1996, pp. 633-651. }\end{array}$ & Susan J. Linz & January 1997 \\
\hline $\begin{array}{l}\text { No. } 65 \text { Published in: Industrial and Corporate } \\
\text { Change, "On the Sequencing of Privatization } \\
\text { in Transition Economies." Vol. 7, No. 1, } \\
1998 .\end{array}$ & Gautam Ahuja and Sumit K. Majumdar & April 1997 \\
\hline
\end{tabular}

Working Papers are available at: www.wdi.bus.umich.edu 


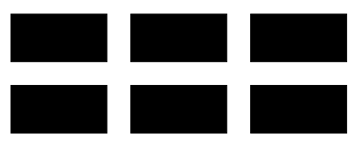

The William Davidson Institute

AT THE UNIVERSITY OF MICHIGAN BUSINESSSCHOOL

\begin{tabular}{|c|c|c|}
\hline $\begin{array}{l}\text { No. 64: Published in: Journal of Law and } \\
\text { Economics, "Foreign Ownership and } \\
\text { Profitability: Property Rights, Control and the } \\
\text { Performance of Firms in Indian Industry" } \\
\text { 42(1), April 1999, pp. 209-38. }\end{array}$ & $\begin{array}{l}\text { Pradeep K. Chhibber and Sumit K. } \\
\text { Majumdar }\end{array}$ & April 1997 \\
\hline $\begin{array}{l}\text { No. 63: How Taxing Is Corruption on } \\
\text { International Investors? }\end{array}$ & Shang-Jin Wei & February 1997 \\
\hline $\begin{array}{l}\text { No. 62: What Can We Learn from the } \\
\text { Experience of Transitional Economies with } \\
\text { Labour Market Policies? }\end{array}$ & Tito Boeri & 1997 \\
\hline $\begin{array}{l}\text { No. 61: Published in: Accounting } \\
\text { Organizations and Society, "Economic } \\
\text { Transition, Strategy and the Evolution of } \\
\text { Management Accounting Practices: The Case } \\
\text { of India" } 24(5,6) \text {, Jul/Aug 1999, pp. 379-412. }\end{array}$ & $\begin{array}{l}\text { Shannon W. Anderson and William N. } \\
\text { Lanen }\end{array}$ & April 1997 \\
\hline $\begin{array}{l}\text { No. 60a: Enterprise Investment During the } \\
\text { Transition: Evidence from Czech Panel Data }\end{array}$ & Lubomír Lizal and Jan Svejnar & December 1997 \\
\hline $\begin{array}{l}\text { No. 59: Published in: Journal of Law, } \\
\text { Economics, and Organization, "Institutional } \\
\text { Environment, Community Government, and } \\
\text { Corporate Governance: Understanding } \\
\text { China's Township-Village Enterprises." 14(1), } \\
\text { April 1998, pages 1-23 }\end{array}$ & Jiahua Che and Yingyi Qian & April 1997 \\
\hline $\begin{array}{l}\text { No. 58: From the Grabbing Hand to the } \\
\text { Helping Hand }\end{array}$ & Jiahua Che & June 2000 \\
\hline $\begin{array}{l}\text { No. 57: Published in: Brookings Papers on } \\
\text { Economic Activity, "The Unofficial Economy } \\
\text { in Transition." 1: } 1998 \text {. }\end{array}$ & $\begin{array}{l}\text { Simon Johnson, Daniel Kaufmann, and } \\
\text { Andrei Schleifer }\end{array}$ & June 1997 \\
\hline $\begin{array}{l}\text { No. 56: Taxes and Government Incentives: } \\
\text { Eastern Europe vs. China }\end{array}$ & Roger H. Gordon and David D. Li & April 1997 \\
\hline No. 55: Corruption and Reform & Susanto Basu and David Li & June 1996 \\
\hline $\begin{array}{l}\text { No. 54: Decentralization and the } \\
\text { Macroeconomic Consequences of } \\
\text { Commitment to State-Owned Firms }\end{array}$ & Loren Brandt and Xiaodong Zhu & June 1997 \\
\hline $\begin{array}{l}\text { No. 53: Published in: The International } \\
\text { Journal of Industrial Organization, } \\
\text { "Competitive Shocks and Industrial Structure: } \\
\text { The Case of Polish Manufacturing." August, } \\
\text { 1999. . }\end{array}$ & Pankaj Ghemawat and Robert E. Kennedy & May 1997 \\
\hline $\begin{array}{l}\text { No. 52: Published in: The Quarterly Journal of } \\
\text { Economics, "Insecure Property Rights and } \\
\text { Government Ownership of Firms." May, } \\
1998 .\end{array}$ & Jiahua Che and Yingyi Qian & May 1997 \\
\hline $\begin{array}{l}\text { No. 51: Incentives, Scale Economies, and } \\
\text { Organizational Form }\end{array}$ & $\begin{array}{l}\text { Eric Maskin, Yingyi Qian, and Chenggang } \\
\mathrm{Xu}\end{array}$ & May 1997 \\
\hline $\begin{array}{l}\text { No. 50: Published in: Post-Soviet-Affairs, } \\
\text { "End of the Tunnel? The Effects of Financial } \\
\text { Stabilization in Russia" April-June 1997, } \\
\text { pages 105-33 }\end{array}$ & $\begin{array}{l}\text { Barry W. Ickes, Peter Murrell, and Randi } \\
\text { Ryterman }\end{array}$ & March 1997 \\
\hline $\begin{array}{l}\text { No. 49: The Evolution of Bank Credit Quality } \\
\text { in Transition: Theory and Evidence from } \\
\text { Romania }\end{array}$ & Enrico C. Perotti and Octavian Carare & October 1996 \\
\hline
\end{tabular}

Working Papers are available at:

www.wdi.bus.umich.edu 


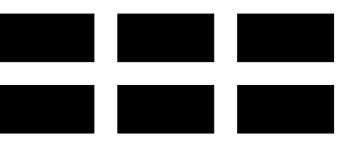

THE WILLIAM DAVIDSON INSTITUTE AT THE UNIVERSITY OF MICHIGAN BUSINESSSCHOOL

\begin{tabular}{|c|c|c|}
\hline $\begin{array}{l}\text { No. 48: Where Do the Leaders Trade? } \\
\text { Information Revelation and Interactions } \\
\text { Between the Segments of Czech Capital } \\
\text { Markets }\end{array}$ & Jan Hanousek and Libor Nemecek & May 1997 \\
\hline $\begin{array}{l}\text { No. 47: Firms' Heterogeneity in Transition: } \\
\text { Evidence from a Polish Panel Data Set }\end{array}$ & Irena Grosfeld and Jean-François Nivet & May 1997 \\
\hline $\begin{array}{l}\text { No. 46: Strategic Creditor Passivity, } \\
\text { Regulation, and Bank Bailouts }\end{array}$ & Janet Mitchell & May 1997 \\
\hline $\begin{array}{l}\text { No. 45a: Published in: Journal of Public } \\
\text { Economics, "Tax Rights in Transition } \\
\text { Economies: A Tragedy of the Commons." 76, } \\
\text { 2000, pp. 369-397 }\end{array}$ & Daniel M. Berkowitz and Wei Li & September 1997 \\
\hline $\begin{array}{l}\text { No. 44a: The Information Content of Stock } \\
\text { Markets: Why do Emerging Markets have } \\
\text { Synchronous Stock Price Movements? } \\
\text { (forthcoming in the Journal of Financial } \\
\text { Economics). }\end{array}$ & $\begin{array}{l}\text { Randall Morck, Bernard Yeung, and } \\
\text { Wayne Yu }\end{array}$ & February 1999 \\
\hline $\begin{array}{l}\text { No. 43: Agency in Project Screening and } \\
\text { Termination Decisions: Why Is Good Money } \\
\text { Thrown After Bad? }\end{array}$ & Chong-en Bai and Yijiang Wang & May 1997 \\
\hline $\begin{array}{l}\text { No. 42: Published in: Economics of } \\
\text { Transition, "Channels of Redistribution: } \\
\text { Inequality and Poverty in the Russian } \\
\text { Transition." Vol. } 7 \text { (2) } 1999 .\end{array}$ & $\begin{array}{l}\text { Simon Commander, Andrei } \\
\text { Tolstopiatenko, and Ruslan Yemtsov }\end{array}$ & May 1997 \\
\hline $\begin{array}{l}\text { No. 41: Published in: Economics of } \\
\text { Transition, "Labour Market Characteristics } \\
\text { and Profitability: Econometric Analysis of } \\
\text { Hungarian Exporting Firms, 1986-1995" 6(1), } \\
\text { May 1998, pages 145-62 }\end{array}$ & László Halpern and Gabor Korosi & May 1997 \\
\hline $\begin{array}{l}\text { No. 40: Published in: the Harvard Law } \\
\text { Review, "The Tragedy of the Anticommons: } \\
\text { Property in the Transition from Marx to } \\
\text { Markets." January } 1998 .\end{array}$ & Michael Heller & February 1997 \\
\hline $\begin{array}{l}\text { No. 39: Privatization and Managerial } \\
\text { Efficiency }\end{array}$ & Olivier Debande and Guido Friebel & May 1997 \\
\hline $\begin{array}{l}\text { No. } 38 \text { Published in: The Quarterly Journal of } \\
\text { Economics, "Disorganization." Vol. 112, No. } \\
\text { 4, November 1997, pp. 1091-1126. }\end{array}$ & Olivier Blanchard and Michael Kremer & January 1997 \\
\hline $\begin{array}{l}\text { No. 37: Published in: Economics of } \\
\text { Transition, "Transition and the Output Fall." } \\
7(1), 1999 \text {, pages 1-28. }\end{array}$ & Gérard Roland and Thierry Verdier & March 1997 \\
\hline $\begin{array}{l}\text { No. 36: Restructuring an Industry During } \\
\text { Transition: A Two-Period Model }\end{array}$ & Richard Ericson & September 1996 \\
\hline $\begin{array}{l}\text { No. 34: The East-West Joint Venture: BC } \\
\text { Torsion Case Study }\end{array}$ & Sonia Ferencikova and Vern Terpstra & December 1998 \\
\hline $\begin{array}{l}\text { No. } 33 \text { Published in: Journal of Comparative } \\
\text { Economics, "Quantifying Price Liberalization } \\
\text { in Russia." Vol. 26, No. 4, December 1998, } \\
\text { pp. 735-737. }\end{array}$ & $\begin{array}{l}\text { Daniel Berkowitz, David DeJong, and } \\
\text { Steven Husted }\end{array}$ & December 1998 \\
\hline $\begin{array}{l}\text { No. 32: What Can North Korea Learn from } \\
\text { China's Market Reforms? }\end{array}$ & John McMillan & September 1996 \\
\hline No. 31: Published in : China-Economic- & Yijiang Wang and Chun Chang & March 1997 \\
\hline
\end{tabular}

Working Papers are available at: www.wdi.bus.umich.edu 


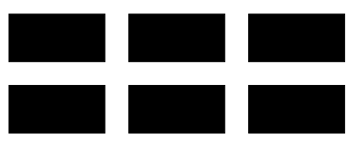

THE WILLIAM DAVIDSON INSTITUTE

AT THE UNIVERSITY OF MICHIGAN BUSINESSSCHOOL

\begin{tabular}{|c|c|c|}
\hline $\begin{array}{l}\text { Review, "Towards a Model of China as a } \\
\text { Partially Reformed Developing Economy } \\
\text { Under a Semifederalist Government.", 9(1), } \\
\text { Spring 1998, pages 1-23. }\end{array}$ & & \\
\hline $\begin{array}{l}\text { No. 30: Convergence in Output in Transition } \\
\text { Economies: Central and Eastern Europe, } \\
\text { 1970-1995 }\end{array}$ & Saul Estrin and Giovanni Urga & February 1997 \\
\hline $\begin{array}{l}\text { No. 29: Published in: Economics of } \\
\text { Transition, "Altered Band and Exchange } \\
\text { Volatility." Volume 6, no. 1, 1998, 173-181. }\end{array}$ & Evzen Kocenda & March 1997 \\
\hline $\begin{array}{l}\text { No. 28: Published in: Quarterly Journal of } \\
\text { Economics, "Public Versus Private Ownership } \\
\text { of Firms: Evidence from Rural China." } \\
\text { Volume 113, no. 3, August 1998, 773-808. }\end{array}$ & Hehui Jin and Yingyi Qian & January 1997 \\
\hline $\begin{array}{l}\text { No. 27: East-West Joint Ventures in a } \\
\text { Transitional Economy: The Case of Slovakia }\end{array}$ & Sonia Ferencikova & March 1997 \\
\hline $\begin{array}{l}\text { No. 26: Published in Economic Analysis } \\
\text { "Behavior of a Slovenian Firm in Transition" } \\
\text { Vol. 1, no. 1, 1998, 57-73. }\end{array}$ & Janez Prasnikar & February 1997 \\
\hline $\begin{array}{l}\text { No. 25: Cultural Encounters and Claims to } \\
\text { Expertise in Postcommunist Capitalism }\end{array}$ & Michael D. Kennedy & February 1997 \\
\hline $\begin{array}{l}\text { No. 24: ZVU a.s.: Investment Funds on the } \\
\text { Board of Directors of an Engineering Giant }\end{array}$ & Tory Wolff & August 1995 \\
\hline $\begin{array}{l}\text { No. 23: The Role of Investment Funds in the } \\
\text { Czech Republic (joint publication with Czech } \\
\text { Management Center) }\end{array}$ & Dusan Triska & June 1996 \\
\hline $\begin{array}{l}\text { No. 22: Czech Investment Fund Industry: } \\
\text { Development and Behaviour (joint publication } \\
\text { with Czech Management Center) }\end{array}$ & Richard Podpiera & May 1996 \\
\hline $\begin{array}{l}\text { No. 21: Restructuring of Czech Firms: An } \\
\text { Example of Gama, a.s. (joint publication with } \\
\text { Czech Management Center) }\end{array}$ & Antonin Bulin & June 1996 \\
\hline $\begin{array}{l}\text { No. 20: YSE Funds: A Story of Czech } \\
\text { Investment Funds (joint publication with } \\
\text { Czech Management Center) }\end{array}$ & Michal Otradovec & November 1995 \\
\hline $\begin{array}{l}\text { No. 19: První Investicni a.s., The First } \\
\text { Investment Corporation (joint publication } \\
\text { with Czech Management Center) }\end{array}$ & Jaroslav Jirasek & August 1995 \\
\hline $\begin{array}{l}\text { No. 18: PPF a.s., The First Private Investment } \\
\text { Fund (joint publication with Czech } \\
\text { Management Center) }\end{array}$ & Michal Otradovec & November 1995 \\
\hline $\begin{array}{l}\text { No. } 17 \text { Published in: Post-Soviet Geography } \\
\text { and Economics, "Russia's Managers in } \\
\text { Transition: Pilferers or Paladins?" Vol. 37, } \\
\text { o.7 (September 1996), pp. 397-426. }\end{array}$ & Susan J. Linz and Gary Krueger & November 1996 \\
\hline $\begin{array}{l}\text { No. 16: Banks in Transition-Investment } \\
\text { Opportunities in Central Europe and Russia } \\
\text { Edited Transcript from } 31 \text { May } 1996 \\
\text { Conference in New York City }\end{array}$ & $\begin{array}{l}\text { With commentary and edited by Anna } \\
\text { Meyendorff }\end{array}$ & January 1997 \\
\hline $\begin{array}{l}\text { No. 15: Marketing in Transitional Economies: } \\
\text { Edited Transcript \& Papers from } 1 \text { April } 1996 \\
\text { Conference in Ann Arbor, Michigan }\end{array}$ & Compiled by The Davidson Institute & December 1996 \\
\hline
\end{tabular}

Working Papers are available at:

www.wdi.bus.umich.edu 


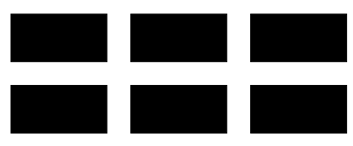

THE WILLIAM DAVIDSON INSTITUTE AT THE UNIVERSITY OF MICHIGAN BUSINESSSCHOOL

\begin{tabular}{|c|c|c|}
\hline $\begin{array}{l}\text { No. 14: Pensions in the Former Soviet Bloc: } \\
\text { Problems and Solutions. Published by } \\
\text { Council on Foreign Relations. "The Coming } \\
\text { Global Pension Crisis" New York, } 1997\end{array}$ & Jan Svejnar & November 1996 \\
\hline $\begin{array}{l}\text { No. 13: Enterprise Restructuring and } \\
\text { Performance in the Transition. Forthcoming } \\
\text { in Financial Systems in Transition: The } \\
\text { Design of Financial Systems in Central } \\
\text { Europe eds. Anna Meyendorff and Anjan } \\
\text { Thakor. }\end{array}$ & $\begin{array}{l}\text { Lubomir Lizal, Miroslav Singer, and Jan } \\
\text { Svejnar }\end{array}$ & December 1996 \\
\hline $\begin{array}{l}\text { No. } 12 \text { Published in: Journal of International } \\
\text { Marketing, "Executive Insights: Marketing } \\
\text { Issues and Challenges in Transitional } \\
\text { Economies." Vol. 5, No. 4, 1997, pp. 95-114. } \\
\text { Also published in: Marketing Issues in } \\
\text { Transitional Economies ed. Rajeev Batra. }\end{array}$ & Rajeev Batra & April 1997 \\
\hline $\begin{array}{l}\text { No. 11: Worker Trust and System } \\
\text { Vulnerability in the Transition from Socialism } \\
\text { to Capitalism }\end{array}$ & Andrew Schotter & August 1996 \\
\hline $\begin{array}{l}\text { No. } 10 \text { Published in: Comparative Economic } \\
\text { Studies, "Russian Firms in Transition: } \\
\text { Champions, Challengers, and Chaff." Vol. 39, } \\
\text { No.2, Summer 1997, pp. 1-36. }\end{array}$ & Susan J. Linz & July 1996 \\
\hline $\begin{array}{l}\text { No. 9: Corporate Debt Crisis and Bankruptcy } \\
\text { Law During the Transition: The Case of China }\end{array}$ & David D. Li and Shan Li & December 1995 \\
\hline $\begin{array}{l}\text { No. } 8 \text { Published in: Journal of Comparative } \\
\text { Economics, "A Theory of Ambiguous } \\
\text { Property Rights in Transition Economies: The } \\
\text { Case of the Chinese Non-State Sector." Vol. } \\
\text { 23, No. 1, August 1996, pp. 1-19. }\end{array}$ & David D. Li & June 1996 \\
\hline $\begin{array}{l}\text { No. 7: The Foreign Economic Contract Law of } \\
\text { China: Cases and Analysis }\end{array}$ & Dong-lai Li & June 1993 \\
\hline $\begin{array}{l}\text { No. 3: Bank Privatization in Hungary and the } \\
\text { Magyar Kulkereskedelmi Bank Transaction }\end{array}$ & Roger Kormendi and Karen Schnatterly & May 1996 \\
\hline $\begin{array}{l}\text { Replacing Nos. 1-2 \& 4-6: Journal of } \\
\text { Comparative Economics Symposium on } \\
\text { "Bank Privatization in Central Europe and } \\
\text { Russia." Vol. 25, No. 1, August } 1997 .\end{array}$ & $\begin{array}{l}\text { No. } 1 \text { "Bank Privatization in Transitional } \\
\text { Economies" by Roger Kormendi and } \\
\text { Edward Snyder. No. } 2 \text { "Transactional } \\
\text { Structures of Bank Privatizations in } \\
\text { Central Europe and Russia" by Anna } \\
\text { Meyendorff and Edward A. Snyder. No. } 4 \\
\text { "Bank Privatization in Poland: The Case of } \\
\text { Bank Slaski" by Jeffery Abarbaness and } \\
\text { John Bonin. No. } 5 \text { "Bank Privatization in } \\
\text { Post-Communist Russia: The Case of } \\
\text { Zhilsotsbank" by Jeffery Abarbanell and } \\
\text { Anna Meyendorff and No. } 6 \text { "'"The Czech } \\
\text { Republic's Commercial Bank: Komercni } \\
\text { Banka" by Edward A. Snyder and Roger } \\
\text { C. Kormendi. }\end{array}$ & August 1997 \\
\hline
\end{tabular}

Working Papers are available at: www.wdi.bus.umich.edu 